\title{
Analysis of the agro-industrial system in the region of Balsas - MA between the years from 2005 to 2017
}

\author{
${ }^{1}$ Gustavo de Oliveira Barbosa; ${ }^{2}$ Nilton Marques de Oliveira; ${ }^{2}$ Fernando Silva Lima \\ ${ }^{1}$ Federal University of Tocantins (UFT), Faculty of Economics, Palmas - Tocantins, Brazil \\ ${ }^{2}$ Federal University of Tocantins (UFT), Post-Graduation Program in Regional Development, Palmas - Tocantins, Brazil.
}

Correspondence Author: Av. Colares Moreira, 477 - Jardim Renascenca, São Luís - MA, Brazil.

E-mail: fernando.silva@ifma.edubr

Received date: 18 March 2019, Accepted date: 5 May, Online date: 25 May 2019

Copyright: $\odot 2019$ Gustavo de Oliveira Barbosa et al., This is an open-access article distributed under the terms of the Creative Commons Attribution License, which permits unrestricted use, distribution, and reproduction in any medium, provided the original author and source are credited.

\begin{abstract}
This study looking for to analyzes in general form the agroindustrial system in the city of Balsas - MA relating and evidencing the study with the data collected in secondary bases. The migration of soy to microregion in mid 80's, starting of genectcs alterations and adaptations in soil made with the region attracted a lot of large landowners making the region appropriate to culture cultivation, showing up since the beginning the emergence of agroindustrial complex in the city. We are interested to analyze and to understand the economic dynamic in the city as well as for the microregion. The methodology adopted was based on a bibliographical review, a priori, after the theoretical construction, secondary data analysis gived for IBGE and RAIS. The results showed the concentration and attraction that city of Balsas over other micro region's cities, evidencing, therefore, the existence of a relative agroindustrial complex in the county.
\end{abstract}

Keywords: Agroindustrial Complex. Farming. Balsas. Maranhão

\section{INTRODUCTION}

In the micro region of Gerais de Balsas in the state of Maranhão, agriculture and grain production began to develop on a large scale in the late 1980s, with the soybean crop adapted to the cerrado and the railroad system under consolidation. Since 1980 with the works of the Great Carajás Project, whose main works in Maranhão were the Carajás Railway Road (EFC) that the steel poles in Açailândia and Bacabeira became references. During the same period, the Port of Itaqui in São Luís became one of the main outlets for the production of ores and intermediary steel products.

Studies such as those by Dörner (2017, p.21) state that the conclusion of the North-South Railroad and the Maranhão Grain Terminal (TEGRAM) also created more favorable logistic conditions for logistics in the state. Placing, the state of Maranhão in a strategic position and has been constituted as an alternative way of socioeconomic development in Brazil.

Based on this principle, we will analyze the main variables related to regional economic development and their importance for the regional development model for the Balsas Region, as well as answer some questions: Similar to the coffee period, we now have soy, because Are soybean yields not used as a source of industrial development in the region? What are the main variables responsible for the evolution of development in the region?

It is in this context that the research problem is constituted, referring to the same questions raised by Silva (1996) because the region of Balsas in the state of Maranhão, as well as other agricultural regions, which have economic surpluses provided by the rural complex does not generate large and long-lasting development? Does the so-called "historic opportunity" have such a decisive force for development in these regions? What contribution does the agroindustrial system have to the region's socioeconomic?

Thus, the general objective of this study is to understand the economic development capacity of the Balsas - MA region based on the main variables addressed by the localization and regional growth theory between 2005 and 2017. The specific objectives are: to collect the data referring to the variables that will be used for the analysis of the agroindustrial system of the region of Balsas MA; analyze the economic growth in each sector of the municipalities of the Microregion of Gerais de Balsas; understand the dynamics of the sectors of the Microregion of Gerais de Balsas in relation to the Microregions of the state of Maranhão. 
Citation: Gustavo de Oliveira Barbosa, et al., Analysis of the agro-industrial system in the region of Balsas - MA between the years from 2005 to 2017. Australian Journal of Basic and Applied Sciences, 13(5): 64-84. DOI: 10.22587/ajbas.2019.13.5.8

\section{THEORETICAL ASPECT 1.1. National Conjuncture}

Table 1 shows in general the number of agricultural establishments and the area of these establishments in hectares for the year 2017 according to the preliminary data of the last Agricultural Census.

Table 1. General relation of number of agricultural establishments and area of agricultural establishments by state for the year 2017.

\begin{tabular}{|c|c|c|c|c|}
\hline States & $\begin{array}{l}\text { Number of } \\
\text { agricultural } \\
\text { establishments } \\
\text { (Units) }\end{array}$ & $\begin{array}{l}\text { Area of } \\
\text { agricultural } \\
\text { establishments } \\
\text { (Hectares) }\end{array}$ & $\begin{array}{l}\text { Percentage in } \\
\text { relation to the } \\
\text { number } \\
\begin{array}{l}\text { agricultural } \\
\text { establishments }\end{array}\end{array}$ & $\begin{array}{l}\text { Percentage in } \\
\text { relation to the area } \\
\text { of agricultural } \\
\text { establishments }\end{array}$ \\
\hline Rondônia & 91.437 & 9.219 .932 & $1,8 \%$ & $2,6 \%$ \\
\hline Acre & 37.343 & 4.230 .216 & $0,7 \%$ & $1,2 \%$ \\
\hline Amazonas & 80.914 & 4.042 .318 & $1,6 \%$ & $1,2 \%$ \\
\hline Roraima & 16.850 & 2.624 .880 & $0,3 \%$ & $0,7 \%$ \\
\hline Pará & 281.704 & 29.677 .672 & $5,6 \%$ & $8,5 \%$ \\
\hline Amapá & 8.507 & 1.506 .294 & $0,2 \%$ & $0,4 \%$ \\
\hline Tocantins & 63.691 & 14.857 .426 & $1,3 \%$ & $4,2 \%$ \\
\hline Maranhão & 219.765 & 12.233 .613 & $4,3 \%$ & $3,5 \%$ \\
\hline Piauí & 245.623 & 9.996 .869 & $4,8 \%$ & $2,9 \%$ \\
\hline Ceará & 394.317 & 6.895 .413 & $7,8 \%$ & $2,0 \%$ \\
\hline Rio Grande do Norte & 63.411 & 2.697 .019 & $1,3 \%$ & $0,8 \%$ \\
\hline Paraíba & 163.217 & 3.426 .132 & $3,2 \%$ & $1,0 \%$ \\
\hline Pernambuco & 281.675 & 4.470 .433 & $5,6 \%$ & $1,3 \%$ \\
\hline Alagoas & 98.534 & 1.634 .862 & $1,9 \%$ & $0,5 \%$ \\
\hline Sergipe & 93.333 & 1.456 .813 & $1,8 \%$ & $0,4 \%$ \\
\hline Bahia & 762.620 & 27.831 .883 & $15,0 \%$ & $7,9 \%$ \\
\hline Minas Gerais & 607.448 & 37.900 .000 & $12,0 \%$ & $10,8 \%$ \\
\hline Espírito Santo & 108.010 & 3.234 .529 & $2,1 \%$ & $0,9 \%$ \\
\hline Rio de Janeiro & 65.157 & 2.372 .778 & $1,3 \%$ & $0,7 \%$ \\
\hline São Paulo & 188.643 & 16.469 .975 & $3,7 \%$ & $4,7 \%$ \\
\hline Paraná & 305.115 & 14.736 .374 & $6,0 \%$ & $4,2 \%$ \\
\hline Santa Catarina & 183.065 & 6.446 .155 & $3,6 \%$ & $1,8 \%$ \\
\hline Rio Grande do Sul & 365.052 & 21.680 .991 & $7,2 \%$ & $6,2 \%$ \\
\hline Mato Grosso do Sul & 70.710 & 29.159 .983 & $1,4 \%$ & $8,3 \%$ \\
\hline Mato Grosso & 118.676 & 54.830 .819 & $2,3 \%$ & $15,7 \%$ \\
\hline Goiás & 152.089 & 26.362 .901 & $3,0 \%$ & $7,5 \%$ \\
\hline Distrito Federal & 5.246 & 257.047 & $0,1 \%$ & $0,1 \%$ \\
\hline Total & 5.072 .152 & 350.253 .327 & $100 \%$ & $100 \%$ \\
\hline
\end{tabular}

Source: Prepared by the author based on data from the IBGE - Agricultural Census (2017).

Note 1: Values referring to the Preliminary Results of the Agricultural Census of 2017.

For the purposes of analysis, it is worth mentioning that in Brazil, up to the Census, there are 5,072,152 units producing some agricultural product, of which 762,620 are located in the state of Bahia, corresponding to $15.0 \%$ of the total number of the country, followed by the states of Minas Gerais, with 607,448 corresponding to $12.0 \%$, Ceará with 394,317 corresponding to $7.8 \%$, and Rio Grande do Sul with 365,052 corresponding to 7.2\% of Maranhão ranks 9th in the ranking with 188,643 agricultural establishments, corresponding to $4.3 \%$ of the total amount of the country.

The numbers are reversed when looking at the area of the agricultural establishments of the country, showing an inverse trend to the number of establishments, that is, the larger the number of agricultural establishments the smaller the agricultural areas will 
be, in this case, agricultural establishments with the largest areas of the country are in the State of Mato Grosso with 54,830,819 hectares in the total amount of the units of the state corresponding to $15.7 \%$ of the total of the country, followed by the states of Minas Gerais with 37,900,000 hectares corresponding to 10.8\% Pará with 29,677,672 hectares corresponding to 8.5\% and Mato Grosso do Sul 29,159,983 corresponding to 8.3\%, Maranhão occupies the 11th position in the ranking with 12,233,613 hectares in the total amount of the state units , corresponding to $3.5 \%$ of the total areas of agricultural establishments in the country.

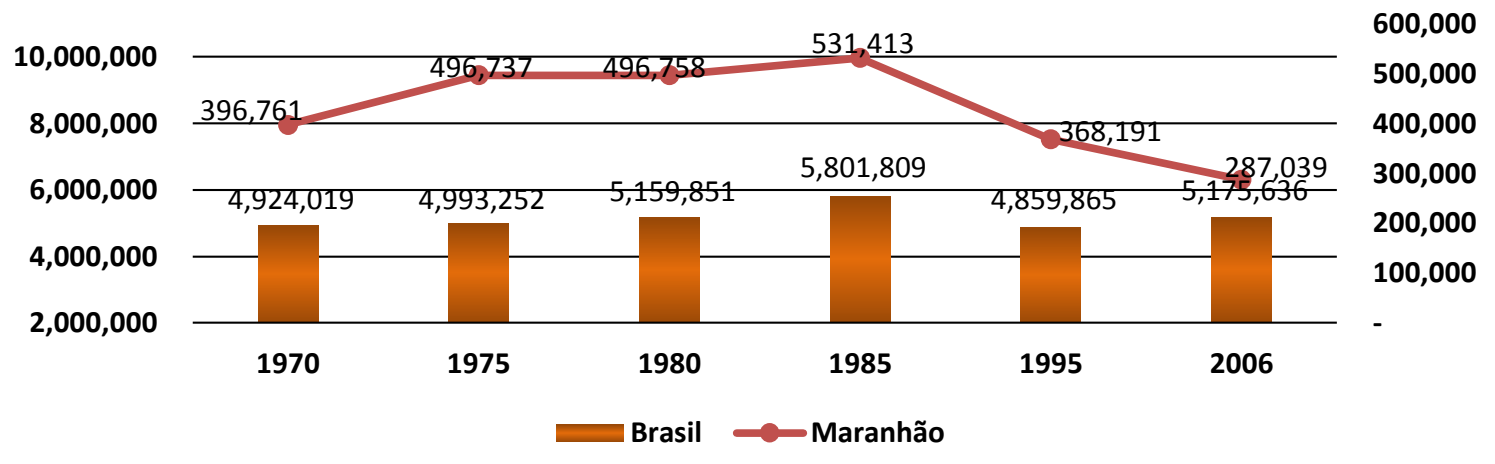

Graph 1. Historical series of the number of agricultural establishments - Relationship between the national and state quantitative(units). Fonte: Elaborado pelo autor a partir dos dados do IBGE - Censo Agropecuário (2006).

Graph 1 shows the historical evolution of the number of agricultural units in the state of Maranhão in relation to the Brazilian quantitative, according to data available by the 2006 Census of Agriculture. One can see in the graph a relevant growth up to 1985, following the national trend, when it registered the largest numbers of the series, corresponding to Brazil with 5,801,809 establishment and in Maranhão with 531,413 establishments. Then, in the next two agricultural censuses, there were systematic falls in the number of establishments in the state of Maranhão, following the first year, corresponding to 1995, the Census registered the Brazilian amount of 4,859,865 establishments, while the Maranhão amount registered 368,191 establishments , the chart ends up showing the values of 2006, presenting the values of the amount of Brazil with 5,175,636 and the state of Maranhão with 287,039 agricultural establishments.

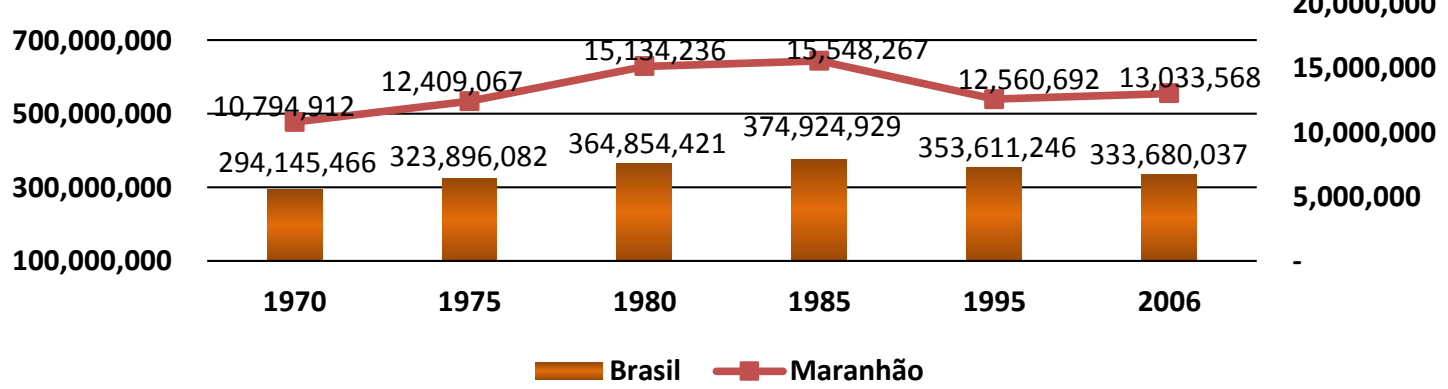

Graph 2. Historical series of the area of agricultural establishments - Relation between the national and state quantitative (Hectares).

Source: Prepared by the author based on data from the IBGE - Agricultural Census (2006).

Graph 2 gives continuity to Graph 1, bringing the area numbers, in hectares, of agricultural establishments, again making a relationship between the state of Maranhão and Brazil. In relation to the national figure in the previous chart, the dynamics of Maranhão follow the national trend with constant growth until the year 1985, in this the Census registered the amount of 374,924,929 hectares in Brazil and 15,548,267 hectares in Maranhão. Then, in 1995, there was a general fall, both in Brazil and in Maranhão, corresponding to 353,611,246 hectares and 12,560,692 hectares respectively, and, lastly, in 2006, although there was a record of a small increase in the general Brazilian amount, corresponding to 333,680,037 hectares, in the state of Maranhão, there was a downward trend, corresponding to 13,033,568 hectares, in the area of agricultural establishments.

Therefore, in relation to Table 1 with graphs 1 and 2, which shows the number of agricultural establishments and area, we can see that the number of agricultural establishments decreased from 287,039 in the year 2006 to 219,765 in the year 2017 , one of about $23.4 \%$ between the two years. Regarding the area of agricultural establishments, this figure also declines, from 13,033,568 hectares in 2006 to $12,233,613$ hectares in 2017 , a fall of $6.1 \%$ between the two years. 


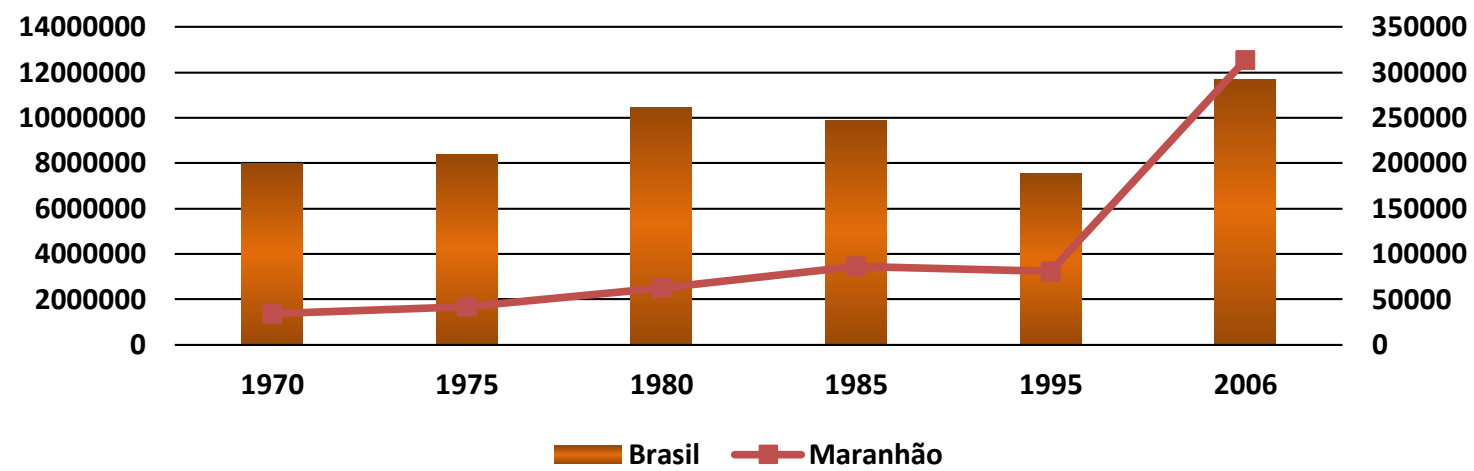

Graph 3. Historical series of the quantitative of permanent crops - Relation between the national and state quantitative (Units) Source: Prepared by the author based on data from the IBGE - Agricultural Census (2006).

Graph 3 shows the relationship between the amount of permanent crops between the Brazilian amount and the maranhense amount according to the 2006 Census of Agriculture. In a similar way to the previous graphs, which are also related to the national and state quantitative, it is noticeable the tendency of national numbers. In the main axis (bars) are the numbers of permanent crops in Brazil, and in the secondary axis (line) the quantitative Maranhão. According to the chart, 2006 was the year with the highest amount of 11,679,152 permanent plantations, up 54.9\% over the previous year, followed by the years 1980 and 1985 of $10,472,135,9,903.487$ respectively. For the state of Maranhão, the same amount was registered, that is, the year 2006 has the largest number of permanent crops with 313,758 units, however its growth represented $289.4 \%$ in relation to the previous year, five times more in relation to national growth for the same period, or more precisely, 5.27\% more, followed by 1985 and 1995 with 86,333 and 80,580 respectively.

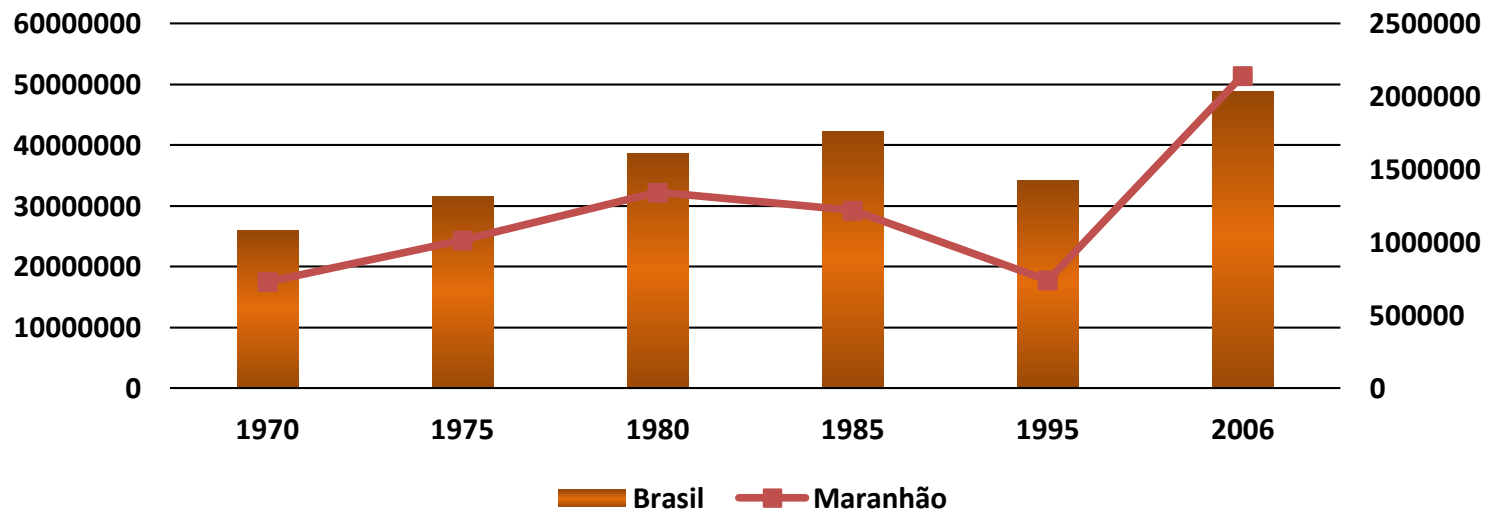

Graph 4. Historical series of the quantitative of temporary crops - Relation between the national and state quantitative (Units) Source: Prepared by the author based on data from the IBGE - Agricultural Census (2006).

Graph 4 shows the relation of the quantitative of temporary crops between the years of 1970 and 2006 according to the Agricultural Census of 2006, with direct relation to the Brazilian amount and the Maranhão amount. Graph 4 behaves in a similar way to Chart 3 showing the largest amounts in 2006 when the records pointed out 48,913,424 establishments throughout the national territory and corresponding to $21,42,810$ in the state of Maranhão. In a similar way to the previous graphs, which are also related to the national and state quantitative, the tendency of the state figures in relation to the national ones is evident. In the main axis (bar) are the numbers of permanent crops in Brazil, and in the secondary axis (line) the quantitative Maranhão, for that, there was a relative growth both in the national and in the state amount, the main difference is the years that before of the year 2006 reached the maximum point of the national amount this maximum point outside the year of 1985 when it reached $42,244,221$ units, in contrast, the state amount reached the maximum point in the year 1980 with 1,342,446 units.

As in the previous Chart, the year 2006 registered a very strong growth, although the amount is not compared to the growth of the permanent crops, the same growth was quite expressive representing $189.1 \%$ of the previous year, and for Maranhão had been registered a rate of $42.8 \%$, or $4.42 \%$ more than the national amount. 


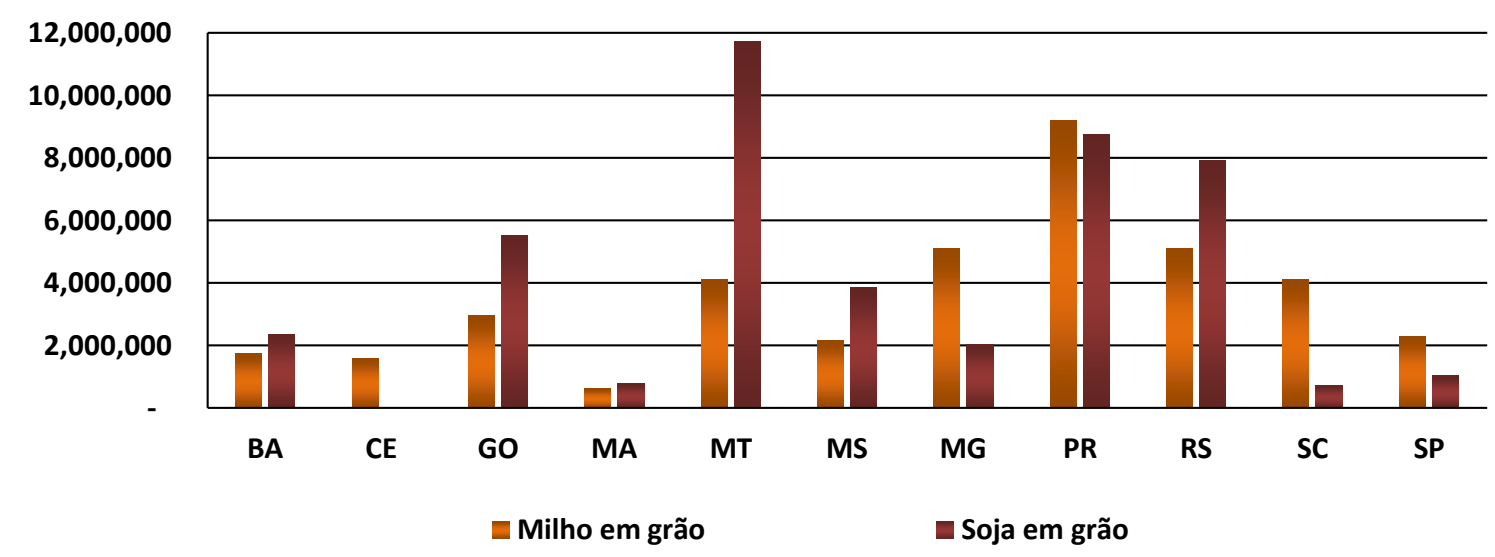

Graph 5. Quantity produced by products of temporary crops for the year 2006 (Tonnes). Source: Prepared by the author based on data from the IBGE - Agricultural Census (2006).

Graph 5 shows the ranking of the production of the temporary crops by the main producing states by products, being these products the corn and the soybean in grains for the year of 2006. For the corn in grain, the state that occupies the first place is the state of Paraná producing 9,195,417 tons, representing $22.2 \%$ of the total production of the country in the analyzed year, followed by the states of Minas Gerais producing 5,118,332 tons, Rio Grande do Sul producing 5,112,210 tons and Mato Grosso producing 4,121 .606 tonnes, representing 12.4\%, 12.3\% and 9.9\% of the country's total production in 2006. These four states mentioned above represent more than half of the country's total production, , $8 \%$ of the country's production, the state of Maranhão occupies the 11th position of the ranking producing 627,234 tons, representing $1.5 \%$ of the total production of the country.

Although there was a concentration of maize production, this concentration was not very large when related to soy production, where the four main soybean producing states in the country concentrate $82.0 \%$ of the total production of the country. Among the main producing states, the first place is occupied by the State of Mato Grosso with the production of 11,747,265 tons of soybeans in 2006 representing $28.4 \%$ of the total national production, followed by Paraná, Rio Grande do Sul and Goiás, producing, respectively, 8,763,847, 7,929,789, 5,514,272 tons produced, these three states represent $53.6 \%$ of the country's production of soybeans in 2006. The state of Maranhão ranks 9th in the ranking, producing 786,174 tonnes representing $1.9 \%$ of Brazil's total production.

\subsection{State and Microregional Context}

The next data analyze the state and microregional economic structure, trying, in this way, to make a relation between the economic dynamics of each one. The following table, Table 2, in general, shows the number of agricultural establishments and the area of agricultural establishments by micro-region in the state of Maranhão for the year 2017, according to the preliminary data of the last Agricultural Census.

The state of Maranhão has a total of 219,765 agricultural establishments totaling 12,233,615 hectares. Of this number, the microregion that has the largest number of agricultural establishments is the micro-region of Baixada Maranhense with a total of 32,893 units, followed by the microregions of Chapadinha with 18,236 middle Mearim with 17,566 establishments and Alto Mearim and Grajaú with 16,582 establishments, of which only the micro-region of Baixada Maranhense represents $15.0 \%$ of the total establishments. It should be noted that the top ten microregions of the ranking represent just over $70 \%$ of the total number of agricultural establishments in the state of Maranhão. The Geral de Balsas micro-region occupies the 18th position among the twenty-one Maranhão micro-regions with 4,846 agricultural establishments, representing 2.2\% of the state's total.

Following the national tendency, the numbers are reversed when analyzing the area of the agricultural establishments of the state of Maranhão, showing an inverse relation when the number of agricultural establishments with their respective areas is contrasted, in other words, it is observed that in microregions that possess the larger numbers of establishments also have the smallest areas, and this also occurs in the opposite way, the microregions that have agricultural establishments with the largest productive areas will soon have a smaller amount of establishments in general. This trend can be observed when the three microregions that have the largest number of establishments are confronted, as the number of establishments is large as soon as their areas become smaller, the micro-region of Baixada Maranhense goes to the 10th position, with the area of establishments totaling 444,857 . 
Citation: Gustavo de Oliveira Barbosa, et al., Analysis of the agro-industrial system in the region of Balsas - MA between the years from 2005 to 2017. Australian Journal of Basic and Applied Sciences, 13(5): 64-84. DOI: 10.22587/ajbas.2019.13.5.8

Table 1. General relationship of the number of agricultural establishments and the area of agricultural establishments by microregion of the state of Maranhão for the year 2017.

\begin{tabular}{|c|c|c|c|c|}
\hline Microregions & $\begin{array}{ll}\text { Number } & \text { of } \\
\text { agricultural } & \\
\text { establishments } & \\
\text { (Units) } & \\
\end{array}$ & $\begin{array}{l}\text { Area of agricultural } \\
\text { establishments } \\
\text { (Hectares) }\end{array}$ & $\begin{array}{l}\text { Percentage in relation to } \\
\text { the number of } \\
\text { agricultural } \\
\text { establishments }\end{array}$ & $\begin{array}{l}\text { Percentage in relation } \\
\text { to the area of } \\
\text { agricultural } \\
\text { establishments }\end{array}$ \\
\hline Litoral Ocidental Maranhense & 8.535 & 30.034 & $3,9 \%$ & $0,2 \%$ \\
\hline Aglomeração Urbana de São Luiz & 2.945 & 4.949 & $1,3 \%$ & $0,0 \%$ \\
\hline Rosário & 7.338 & 32.154 & $3,3 \%$ & $0,3 \%$ \\
\hline Lençóis Maranhenses & 7.830 & 39.785 & $3,6 \%$ & $0,3 \%$ \\
\hline Baixada Maranhense & 32.893 & 444.857 & $15,0 \%$ & $3,6 \%$ \\
\hline Itapecuru Mirim & 8.571 & 146.058 & $3,9 \%$ & $1,2 \%$ \\
\hline Gurupi & 6.631 & 405.070 & $3,0 \%$ & $3,3 \%$ \\
\hline Pindaré & 14.661 & 1.598 .419 & $6,7 \%$ & $13,1 \%$ \\
\hline Imperatriz & 11.678 & 1.760 .822 & $5,3 \%$ & $14,4 \%$ \\
\hline Médio Mearim & 17.566 & 678.754 & $8,0 \%$ & $5,5 \%$ \\
\hline Alto Mearim e Grajaú & 16.582 & 1.596 .645 & $7,5 \%$ & $13,1 \%$ \\
\hline Presidente Dutra & 7.288 & 327.049 & $3,3 \%$ & $2,7 \%$ \\
\hline Baixo Parnaíba Maranhense & 7.864 & 108.684 & $3,6 \%$ & $0,9 \%$ \\
\hline Chapadinha & 18.236 & 404.011 & $8,3 \%$ & $3,3 \%$ \\
\hline Codó & 10.794 & 343.478 & $4,9 \%$ & $2,8 \%$ \\
\hline Coelho Neto & 2.879 & 91.155 & $1,3 \%$ & $0,7 \%$ \\
\hline Caxias & 12.990 & 497.414 & $5,9 \%$ & $4,1 \%$ \\
\hline Chapadas do Alto Itapecuru & 10.009 & 591.173 & $4,6 \%$ & $4,8 \%$ \\
\hline Porto Franco & 5.317 & 797.104 & $2,4 \%$ & $6,5 \%$ \\
\hline Gerais de Balsas & 4.846 & 1.456 .937 & $2,2 \%$ & $11,9 \%$ \\
\hline Chapada das Mangabeiras & 4.312 & 879.063 & $2,0 \%$ & $7,2 \%$ \\
\hline Total & 219.765 & 12.233.615 & $100 \%$ & $100 \%$ \\
\hline
\end{tabular}

Source: Prepared by the author based on data from the IBGE - Agricultural Census (2017).

Note 2: Values referring to the Preliminary Results of the Agricultural Census of 2017.

The first position is now occupied by the micro-region of Imperatriz with a total area of $1,760,822$ hectares, followed by the micro-regions of Pindaré with 1,598,419 hectares, Alto Mearim and Grajaú with 1,596,645 and Gerais de Balsas with 1,456,937. These four microregions account for more than half of the total hectares of the state's agricultural establishments, being more accurate $52.4 \%$, being $14.4 \%, 13.1 \%, 13.1 \%$ and $11.9 \%$, respectively.

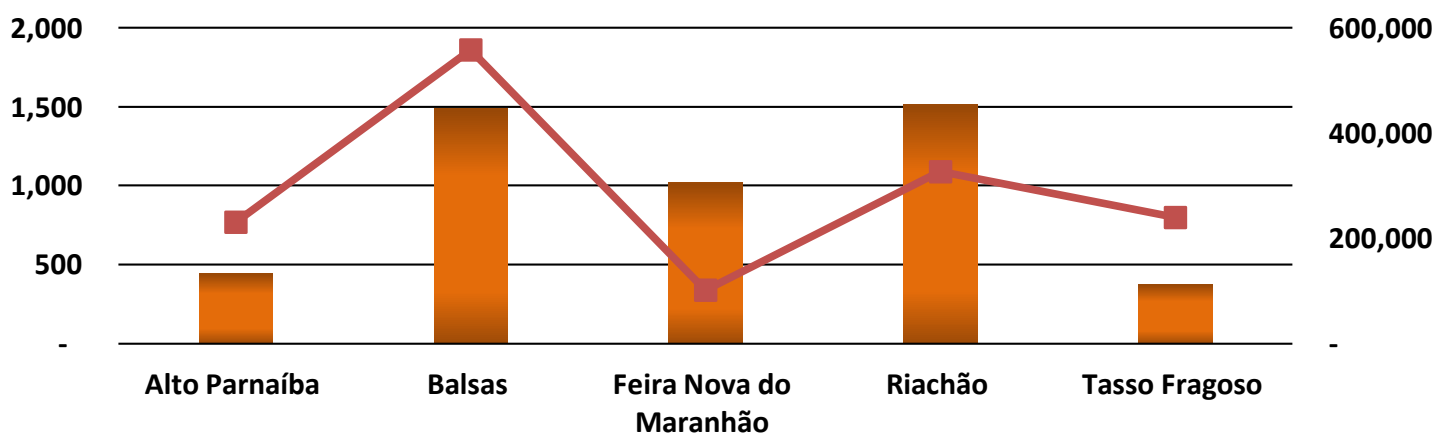

Número de estabelecimentos agropecuários (Un) - Área dos estabelecimentos agropecuários (He)

Graph 6. Number of agricultural establishments (Units) and Area of agricultural establishments (Hectares) for the Microregion of Gerais de Balsas in 2017.

Source: Prepared by the author based on data from the IBGE - Agricultural Census (2017). 
Graph 6 shows the same relation as in Table 2, however, there is a relation between the number of agricultural establishments and the area of agricultural establishments in the municipalities that make up the micro region of Balsas Gerais. In the graph there is the same dynamics found in previous analysis, the municipality with the largest number of agricultural establishments is the municipality of Riachão with 1,515 establishments, followed by Balsas with 1,487, Feira Nova of Maranhão with 1,019, Alto Parnaíba with 447 and, for Tasso Fragoso with 378 agricultural establishments. Only the municipalities of Riachão and Balsas make up more than $60 \%$ of the total numbers of the microregion, accounting for $31.3 \%$ and $30.7 \%$ respectively, while the other municipalities make up less than $40 \%$, representing respectively $21.0 \%, 9.2 \% 7.8 \%$.

The area of agricultural establishments is now led by the municipality of Balsas, with 558,196 hectares representing $38.3 \%$, followed by the municipalities of Riachão with 326,666 hectares representing 22.4\%, Tasso Fragoso with 239,702 hectares representing 16.5\%, Alto Parnaíba with 230,764 hectares representing 15.8\% and Feira Nova do Maranhão with 101,609 representing $7.0 \%$.

The Maranhão production is presented in Graph 7, the planted area, harvested area and production for the harvests of 2017 and 2018 up to the month of September are shown in the same, according to the IBGE data.

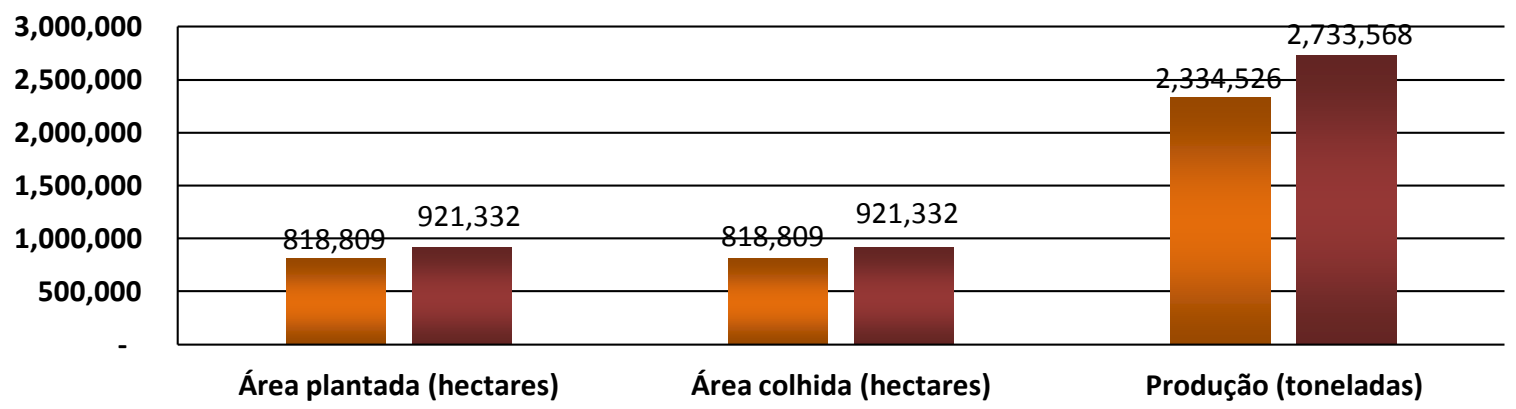

— Safra 2017 - Safra 2018

Graph 7. Comparison between planted area, harvested area and production for the 2017 and 2018 harvests of Maranhão state Source: Prepared by the author based on IBGE - Systematic Survey of Agricultural Production (2017).

Note 1: Harvest of 2018 with values available until the month of September.

For the harvest of 2017, the area planted was 818,809 hectares, the area harvested represented the same amount of the planted area and, for the harvest from 2018 to September, the area planted was 921,332 hectares, representing, thus the same area harvested, with a variation of $12.5 \%$ in both planted and harvested area. Production in the 2017 harvest was 2,334,526 tons and in the 2018 harvest, up to September, it was 2,733,568 tons, an increase of $17.1 \%$ in relation to the previous harvest, in this way one can note the average yield in kilograms per hectare an increase of $4.1 \%$ showing in the 2017 harvest the amount of 2,851 kilograms per hectare and in the harvest 2018 the amount of 2,967 kilograms per hectare.

Table 3 shows the gross domestic product (GDP) at real prices by microregions of the state of Maranhão for the year 2005 and 2015. For the year 2005 the microregions of São Luís, Imperatriz, Pindaré, Caxias, Gerais Balsas, Meio Mearim and Baixada Maranhense have over one billion reais in GDP, these seven microregions concentrate more than 70\% of the state's GDP, the Geral de Balsas micro-region possessed the fifth largest GDP in the state in 2005 with 1,360 .170,00 representing 5.4\% of the GDP of Maranhão.

Table 2. GDP by Microregions at real prices for the years 2005 to 2015 in Thousand Reais.

\begin{tabular}{|l|l|l|}
\hline Microregions & GDP 2005 & GDP 2015 \\
\hline Litoral Ocidental Maranhense & $292.916,00$ & $520.876,21$ \\
\hline Aglomeração Urbana de São Luís & $9.865 .302,00$ & $15.970 .526,16$ \\
\hline Rosário & $346.774,00$ & $654.708,48$ \\
\hline Lençóis Maranhenses & $254.061,00$ & $561.303,32$ \\
\hline Baixada Maranhense & $1.038 .551,00$ & $1.979 .846,51$ \\
\hline Itapecuru Mirim & $372.315,00$ & $858.165,90$ \\
\hline Gurupi & $401.132,00$ & $802.199,36$ \\
\hline Pindaré & $1.488 .376,00$ & $2.678 .298,08$ \\
\hline Imperatriz & $3.326 .931,00$ & $5.480 .662,15$ \\
\hline Médio Mearim & $1.099 .714,00$ & $2.231 .735,24$ \\
\hline Alto Mearim e Grajaú & $645.512,00$ & $1.118 .223,67$ \\
\hline
\end{tabular}


Citation: Gustavo de Oliveira Barbosa, et al., Analysis of the agro-industrial system in the region of Balsas - MA between the years from 2005 to 2017. Australian Journal of Basic and Applied Sciences, 13(5): 64-84. DOI: 10.22587/ajbas.2019.13.5.8

\begin{tabular}{|l|l|l|}
\hline Presidente Dutra & $446.053,00$ & $788.375,40$ \\
\hline Baixo Parnaíba Maranhense & $223.608,00$ & $431.797,65$ \\
\hline Chapadinha & $437.860,00$ & $784.522,12$ \\
\hline Codó & $697.025,00$ & $969.665,24$ \\
\hline Coelho Neto & $246.583,00$ & $356.956,19$ \\
\hline Caxias & $1.377 .293,00$ & $1.814 .315,67$ \\
\hline Chapadas do Alto Itapecuru & $432.625,00$ & $848.378,47$ \\
\hline Porto Franco & $380.018,00$ & $912.968,92$ \\
\hline Gerais de Balsas & $1.360 .170,00$ & $2.174 .631,21$ \\
\hline Chapadas das Mangabeiras & $371.389,00$ & $609.515,61$ \\
\hline
\end{tabular}

Source: Prepared by the author based on IBGE data (2017).

Note 1: IGP-Di deflated values.

For the year 2015, the same microregions that owned more than 70\% of the state's GDP in 2005 are still in the analysis of this, however, in specific aspects the scenario changes, one that the micro-region of Mearim Middle happens to occupy the place that was previously the one occupied by the micro region of Caxias. The Geral de Balsas micro region continues to rank fifth among the state's highest GDPs with 2,174,631.21 representing 5.1\% of total production.

Table 4 can be considered a continuation of Table 3, since it shows the growth rate and average annual growth of the GDP by the microregions of Maranhão, considering for the analysis the same years of 2005 and 2015. Among the microregions with higher rates of growth we have the micro-regions of Porto Franco with 140.2\%, followed by the micro-regions of Itapecuru Mirim, Lençóis Maranhenses, Médio Mearim and Gurupi, all with a growth rate above 100\%, ie doubling their GDP between the years of 2005 and 2015, with their numbers, respectively, being 130.5\%, 120.9\%, 102.9\% and 100.0\%. The Geral de Balsas micro-region recorded a growth rate of $59.9 \%$ among the analyzed years, occupying the 18th position among the microregions of the state of Maranhão.

Table 3. Growth rate and average annual growth rate of GDP at real prices by Microregions between the years 2005 to 2015.

\begin{tabular}{|l|l|l|}
\hline Microregions & Growth rate & Average Annual Growth Rate \\
\hline Litoral Ocidental Maranhense & $77,8 \%$ & $6,3 \%$ \\
\hline Aglomeração Urbana de São Luís & $61,9 \%$ & $5,3 \%$ \\
\hline Rosário & $88,8 \%$ & $7,4 \%$ \\
\hline Lençóis Maranhenses & $120,9 \%$ & $8,6 \%$ \\
\hline Baixada Maranhense & $90,6 \%$ & $6,8 \%$ \\
\hline Itapecuru Mirim & $130,5 \%$ & $9,0 \%$ \\
\hline Gurupi & $100,0 \%$ & $7,5 \%$ \\
\hline Pindaré & $79,9 \%$ & $6,2 \%$ \\
\hline Imperatriz & $64,7 \%$ & $5,4 \%$ \\
\hline Médio Mearim & $102,9 \%$ & $9,3 \%$ \\
\hline Alto Mearim e Grajaú & $73,2 \%$ & $6,0 \%$ \\
\hline Presidente Dutra & $76,7 \%$ & $6,1 \%$ \\
\hline Baixo Parnaíba Maranhense & $93,1 \%$ & $7,5 \%$ \\
\hline Chapadinha & $79,2 \%$ & $7,1 \%$ \\
\hline Codó & $39,1 \%$ & $3,7 \%$ \\
\hline Coelho Neto & $44,8 \%$ & $4,5 \%$ \\
\hline Caxias & $31,7 \%$ & $3,1 \%$ \\
\hline Chapadas do Alto Itapecuru & $96,1 \%$ & $7,3 \%$ \\
\hline Porto Franco & $140,2 \%$ & $11,9 \%$ \\
\hline Gerais de Balsas & $59,9 \%$ & $6,7 \%$ \\
\hline Chapadas das Mangabeiras & $64,1 \%$ & $6,7 \%$ \\
\hline Source: Prpar & \\
\hline
\end{tabular}

Source: Prepared by the author based on IBGE data (2017).

Note 1: IGP-Di deflated values. 
In terms of average annual growth, as expected, the highest rates remain among the microregions that had the highest rates among the analyzed years, the micro-region of Porto Franco had the highest average growth rates, $11.9 \%$ per year, followed of the microregions of Middle Mearim, with a 9.3\% annual average growth, Itapecuru Mirim with 9.0\%, Lençóis Maranhenses with $8.6 \%$ and Gurupi $7.5 \%$. Occupied before the 18th position when analyzing the total growth rate, the micro-region of Gerais de Balsas becomes the 11th largest microregion in the state, analyzing its annual average growth, representing $6.7 \%$ years is responsible for raising this average such as the year 2007 which registered a growth of $56.2 \%$ followed by $22.2 \%$ registered in the year 2012 .

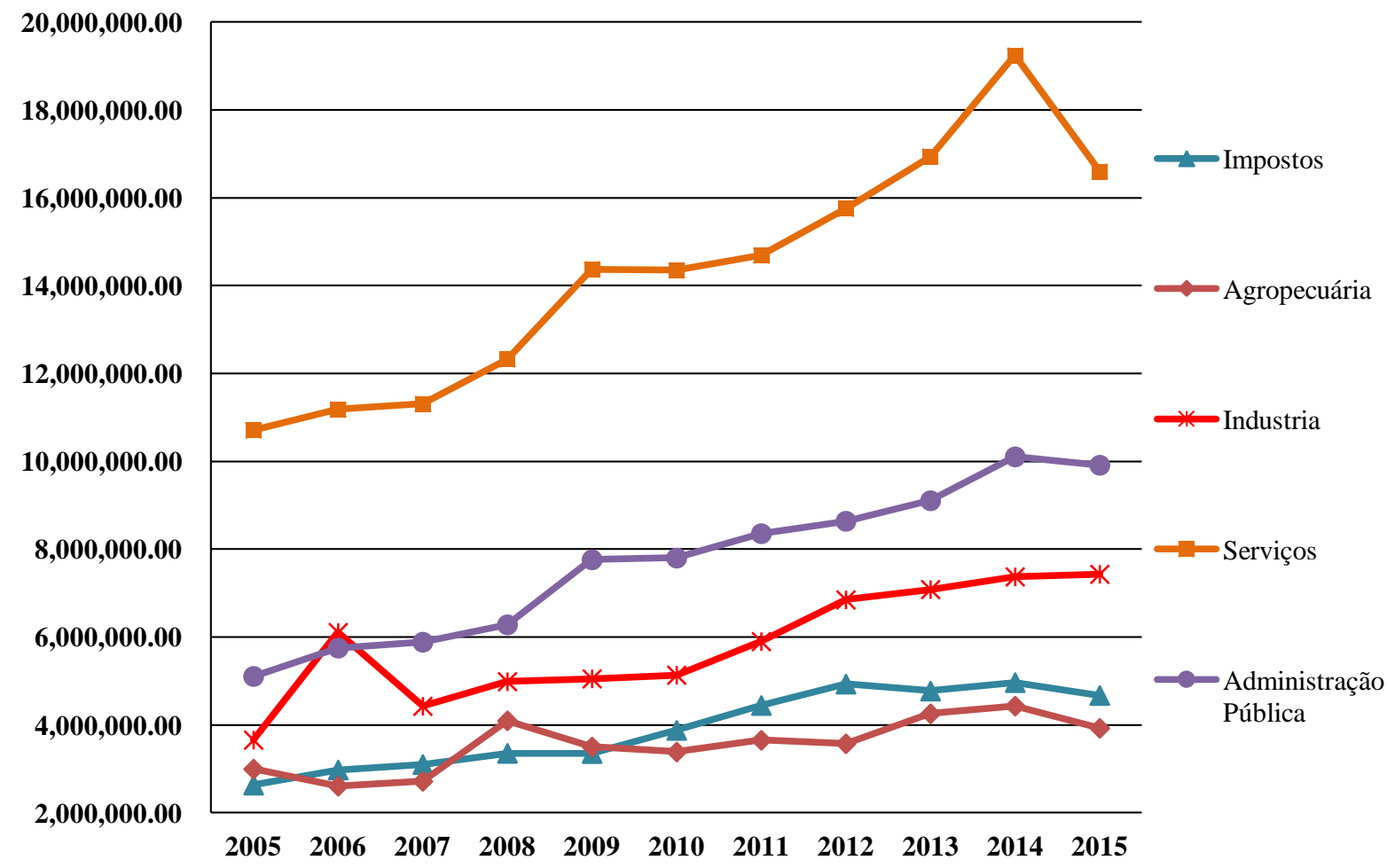

Graph 8. GDP by sectors of the state of Maranhão in Thousand Reais.

Source: Prepared by the author based on IBGE data (2017).

Note 1: IGP-Di deflated values.

Graph 8 shows the dynamics of GDP growth in the state of Maranhão divided by sectors of the economy, services is the main sector in the Maranhão economy registering the highest increase in the year 2014 when it registered the amount of 19,241,560.69 billion reais, followed by 2013 with 16,937,461.83 billion reais and 2015 with 16,599,095.60 billion reais. The second sector of the economy is the public administration with the highest increase in 2014 when it registered the amount of 10,106,309.19 billion reais, followed by 2015 with $9,915,479.50$ billion reais and 2013 with 9,107. 538.86 billion reais. The industry appears to represent the third largest sector of the economy in the state presenting a constant growth since the year 2007 when a significant drop of the previous year, the year of 2006 registered levels higher than the levels of the year of 2011, when they registered 6,107,212, 60 and 5,900,0510.14 billion reais respectively, after such a decline growth was constant until the year 2015 when it registered the highest increase in the series, 7,433,056.45 billion reais. The agricultural sector is the sector with the low est GDP in the state of Maranhão, the highest amount recorded in the year 2014 when it registered 4,431,991.81 billion reais, followed by 2013 with 4,256,928.61 and 2008 with 4,096 .569 .48 billion reais.

Table 5. Growth rate and average annual growth rate of GDP by sectors at real prices between the years 2005 to 2015.

\begin{tabular}{|l|l|l|}
\hline Sectors & Growth rate & Average Annual Growth Rate \\
\hline Impostos & $77,5 \%$ & $6,2 \%$ \\
\hline Agropecuária & $31,0 \%$ & $4,2 \%$ \\
\hline Indústria & $103,2 \%$ & $9,4 \%$ \\
\hline Serviços & $55,0 \%$ & $4,8 \%$ \\
\hline Administração Pública & $94,1 \%$ & $7,1 \%$ \\
\hline
\end{tabular}

Source: Prepared by the author based on IBGE data (2017).

Note 1: IGP-Di deflated values.

Table 5 shows the growth rate and the average annual growth rate of GDP at real prices by sectors between 2005 and 2015 , the data in Table 5 is directly related to the previous graph, of industry showed the highest growth rate among the analyzed years with 
the rate of $103.2 \%$, followed by the public administration sector with $94.1 \%$, taxes, services and agriculture with $77.5 \%, 55.0 \%$ and $31.0 \%$ respectively. Following the trend of the growth rate, the average annual growth rate, the industry sector had a $9.4 \%$ average growth, public administration presented a rate of $7.1 \%$, followed by taxes with $6.2 \%$, services with $4.8 \%$ and agriculture and cattle raising with $4.2 \%$.

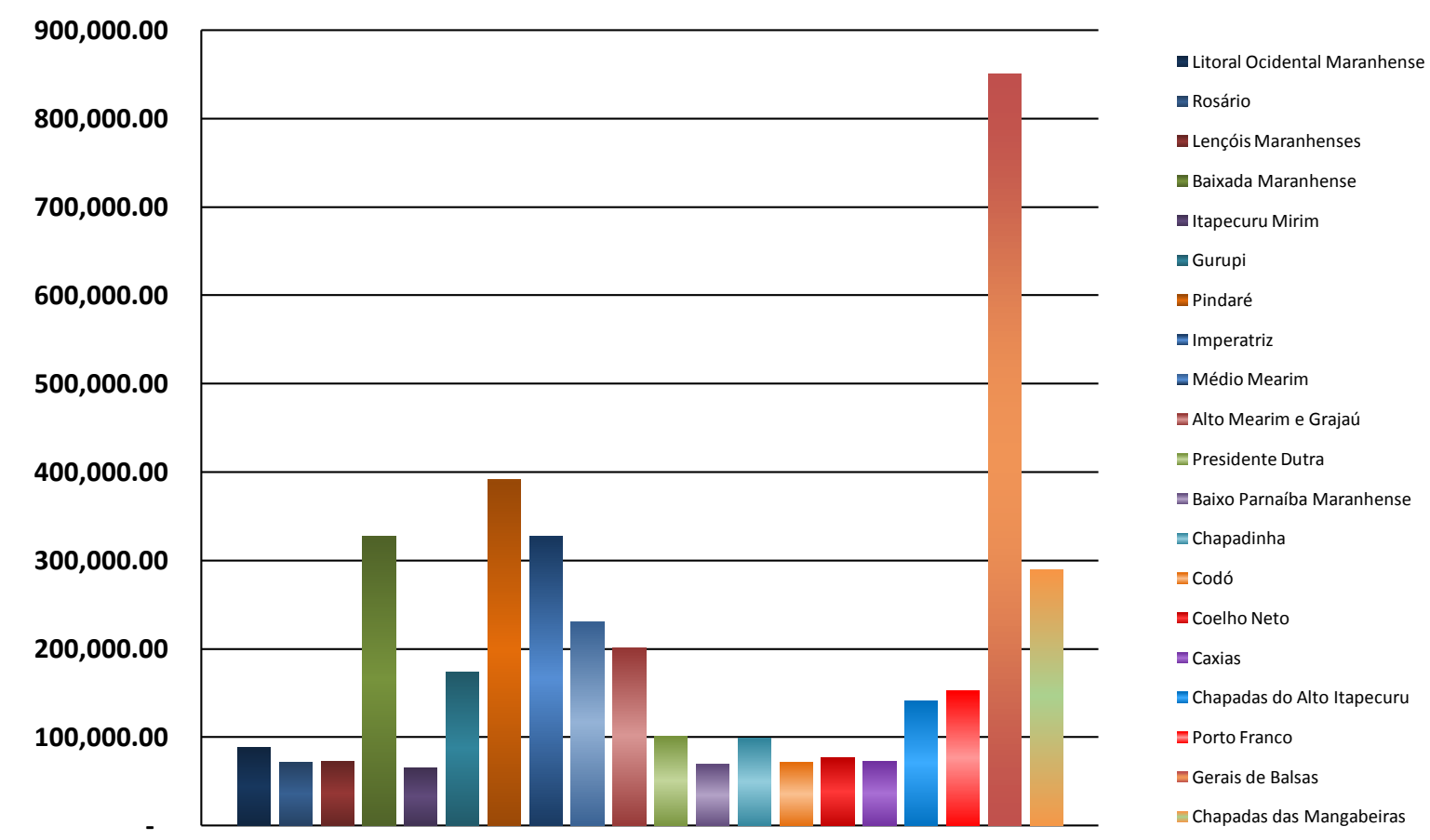

Graph 9. Agricultural GDP by Microregion for 2015 in Thousand Reais

Source: Prepared by the author based on IBGE data (2017).

Note 1: IGP-Di deflated values.

Graph 9 shows the GDP of the agricultural sector by micro-region for the year 2015. Analyzing only the agricultural sector, the micro-region of Gerais de Balsas has the highest GDP among all the microregions of the state with 851,174.49 billion reais, representing $21,7 \%$ of the agricultural GDP of the state, followed by the micro regions of Pindaré with 391,532.64 representing $10.0 \%$, Imperatriz with 327,718.05 representing 8.3\%, Baixada Maranhense with 327,289.18 and Chapadas das Mangabeiras with 290,058.22 billion of real, the microregion of the Urban Agglomeration of São Luís is the one that has the lowest agricultural GDP with 43,977.31 billion reais.

Table 6 refers to the growth rate and the average annual growth rate of Agricultural GDP for the microregions of the state of Maranhão for the period analyzed from the years 2005 to 2015. Although the micro region of Gerais de Balsas has the highest agricultural GDP of the state, Coelho Neto's micro-region showed the highest growth rate with $325.1 \%$, followed by the Rosario micro-regions with 76.2\%, Gerais de Balsas with 68.7\%, Maranhão West Coast with 61.3\% \% and Porto Franco with 55.1\% between the analyzed period, the micro-region of São Luís Urban Agglomeration showed a negative growth of $24.6 \%$ for the agricultural sector.

Table 6. Growth rate and average annual growth rate of agricultural GDP by micro-regions at real prices between the years 2005 to 2015.

\begin{tabular}{|l|l|l|}
\hline Microregions & Growth rate & Average Annual Growth Rate \\
\hline Litoral Ocidental Maranhense & $61,3 \%$ & $5,7 \%$ \\
\hline Aglomeração Urbana de São Luís & $-24,6 \%$ & $-0,9 \%$ \\
\hline Rosário & $76,2 \%$ & $6,5 \%$ \\
\hline Lençóis Maranhenses & $50,3 \%$ & $5,7 \%$ \\
\hline Baixada Maranhense & $31,0 \%$ & $3,7 \%$ \\
\hline Itapecuru Mirim & $-6,8 \%$ & $1,5 \%$ \\
\hline Gurupi & $31,0 \%$ & $4,1 \%$ \\
\hline Pindaré & $11,4 \%$ & $2,4 \%$ \\
\hline Imperatriz & $13,4 \%$ & $1,7 \%$ \\
\hline Médio Mearim & $21,8 \%$ & $3,7 \%$ \\
\hline
\end{tabular}


Citation: Gustavo de Oliveira Barbosa, et al., Analysis of the agro-industrial system in the region of Balsas - MA between the years from 2005 to 2017. Australian Journal of Basic and Applied Sciences, 13(5): 64-84. DOI: 10.22587/ajbas.2019.13.5.8

\begin{tabular}{|l|l|l|}
\hline Alto Mearim e Grajaú & $9,0 \%$ & $1,7 \%$ \\
\hline Presidente Dutra & $9,7 \%$ & $2,5 \%$ \\
\hline Baixo Parnaíba Maranhense & $30,4 \%$ & $7,9 \%$ \\
\hline Chapadinha & $-13,4 \%$ & $6,4 \%$ \\
\hline Codó & $1,9 \%$ & $1,5 \%$ \\
\hline Coelho Neto & $325,1 \%$ & $25,6 \%$ \\
\hline Caxias & $9,4 \%$ & $2,4 \%$ \\
\hline Chapadas do Alto Itapecuru & $37,5 \%$ & $5,4 \%$ \\
\hline Porto Franco & $55,1 \%$ & $5,1 \%$ \\
\hline Gerais de Balsas & $68,7 \%$ & $13,9 \%$ \\
\hline Chapadas das Mangabeiras & $42,6 \%$ & $8,1 \%$ \\
\hline
\end{tabular}

Source: Prepared by the author based on IBGE data (2017).

Note 1: IGP-Di deflated values.

In terms of the average annual growth rate, the highest rate remains the Coelho Neto microregion with $25.6 \%$, followed by the Geral de Balsas micro-region with 13.9\%, Chapadas das Mangabeiras with $8.1 \%$, Baixo Parnaíba Maranhense with $7.9 \%$ and Rosario with $6.5 \%$.

The figure below, figure 1, shows the location of the Gerais de Balsas microregion in the state of Maranhão, the microregion is in the extreme south of the state, bordering the states of Pará, Piauí and Tocantins. The microregion is composed by the municipalities of Alto Paranaíba, Tasso Fragoso, Balsas, Riachão and Feira Nova of Maranhão.

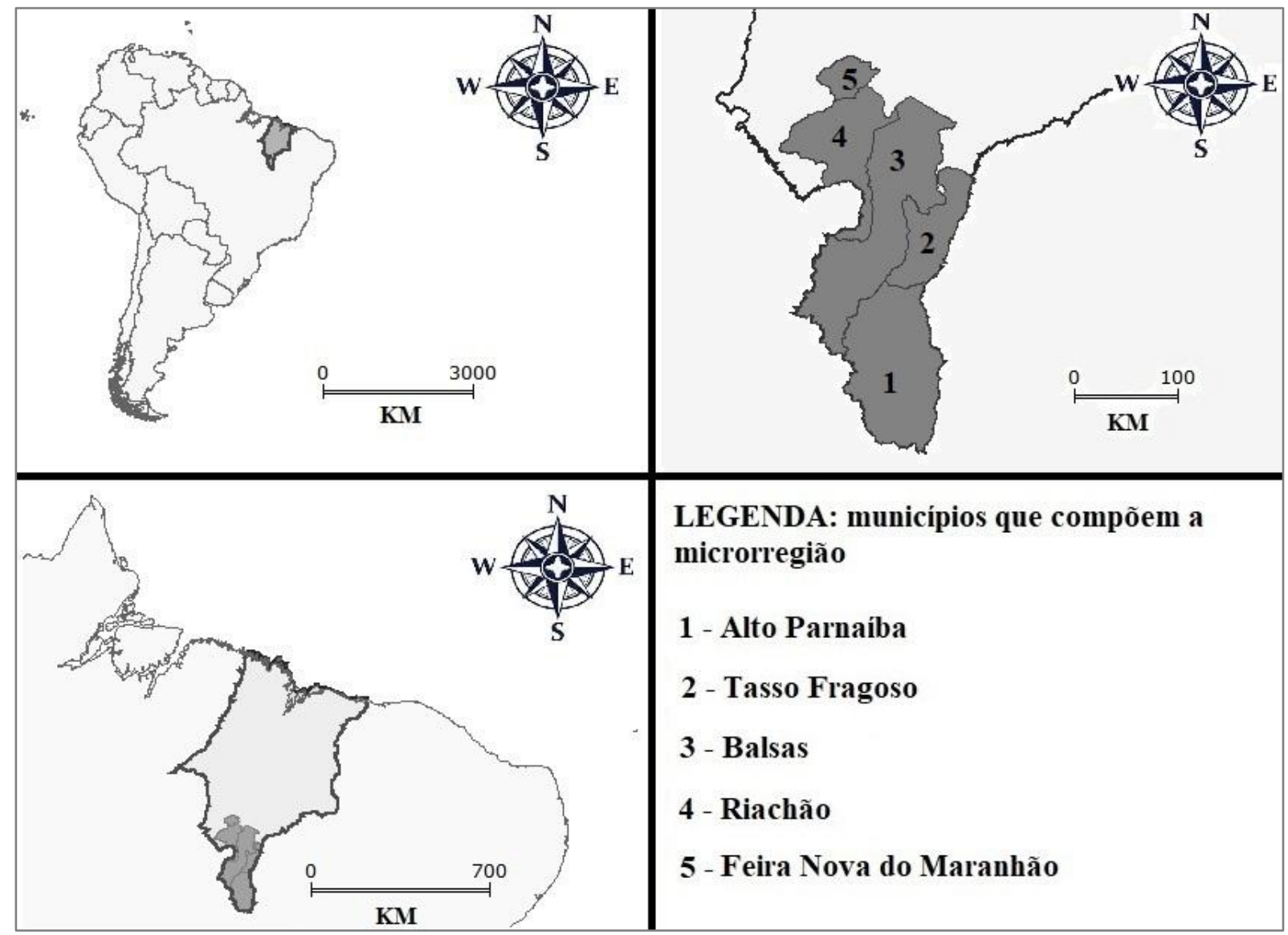

Figure 1. Spatial location of the Geral de Balsas Microregion - MA

Source Prepared by the author based on IBGE data (2017).

Bringing the numbers of municipalities individually in the microregion, Chart 10 alludes to the GDP of each municipality in the micro-region. The municipality of Balsas has the highest GDP among the municipalities of the analyzed micro-region, in 2014 the municipality had the highest GDP of 1,748,982.62 billion reais, followed by 2013 with 1,573,104.25 and 2015 with 1,425,774.24 having one each in the year of 2014, the lowest GDP was in 2007 when it registered the value of 750,063.64 billion reais. The second largest GDP of the microregion is represented by the municipality of Tasso Fragoso, which, like the municipality of 
Citation: Gustavo de Oliveira Barbosa, et al., Analysis of the agro-industrial system in the region of Balsas - MA between the years from 2005 to 2017. Australian Journal of Basic and Applied Sciences, 13(5): 64-84. DOI: 10.22587/ajbas.2019.13.5.8

Balsas, registered the highest increase in 2014 , when it registered the amount of $478,110.37$ million reais, followed by the years 2013 and 2012 with 449,453.64 and 423,623.06 million reais, respectively.

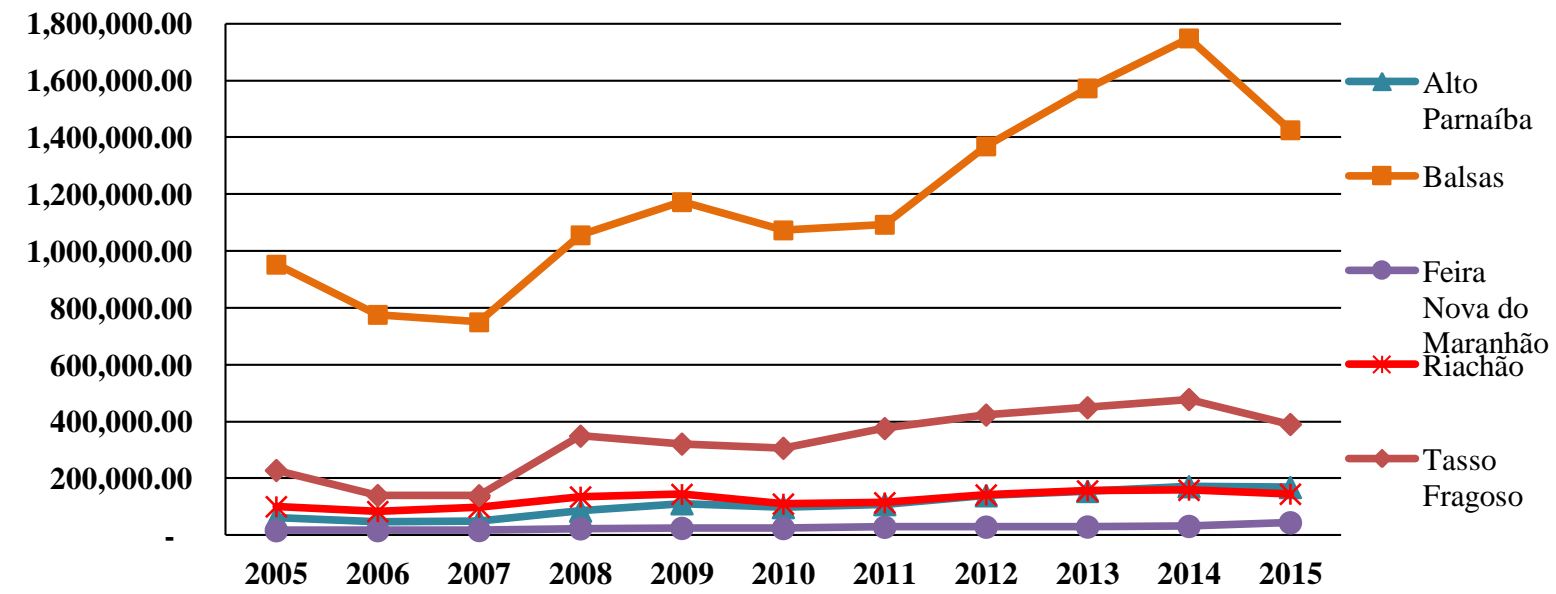

Graph 10. GDP by Municipalities of the Microregion of Gerais de Balsas in Thousand Reais.

Source: Prepared by the author based on IBGE data (2017).

Note 1: IGP-Di deflated values.

Then came the municipality of Alto Parnaíba registering the highest increase also in 2014 with 171,611.39 million reais, in 2015 was recorded the second highest value of GDP of the municipality in the analyzed period, 168,708.01 million reais and in 2013, 154,973.64 million reais. The penultimate lowest GDP of the micro-region is presented in the municipality of Riachão, which also presented in the year of 2014 its highest GDP in the analyzed period, 159,049.82 reais, followed by the years 2013 and 2015 with 156,596.73 and 144,989.26 million reais. The municipality with the lowest GDP in the micro-region of Gerais de Balsas is represented by the municipality of Feira Nova do Maranhão, with 44,672.39 million Reais, the highest increase in the analyzed period in 2015, following the year 2014 with 31,766.75 e 2013 with 29,725.03 million reais.

Table 7. Growth rate and average annual GDP growth rate by Municipalities of the Microregion of Gerais de Balsas at real prices between the years 2005 to 2015 .

\begin{tabular}{|l|l|l|}
\hline Counties & Growth rate & Average Annual Growth Rate \\
\hline Alto Parnaíba & $176,2 \%$ & $13,2 \%$ \\
\hline Balsas & $49,7 \%$ & $5,6 \%$ \\
\hline Feira Nova do Maranhão & $165,5 \%$ & $11,1 \%$ \\
\hline Riachão & $43,6 \%$ & $5,2 \%$ \\
\hline Tasso Fragoso & $70,8 \%$ & $12,8 \%$ \\
\hline
\end{tabular}

Source: Prepared by the author based on IBGE data (2017).

Note 1: IGP-Di deflated values.

Complementing the information in Chart 10, Table 7 shows the growth rate and average annual GDP growth rate of the municipalities of the Gerais de Balsas microregion between the years 2005 to 2015. Although the municipality of Balsas has the largest GDP in the micro-region in the period analyzed, the municipality is only above the municipality of Riachão in terms of growth rate and annual average growth rate, with $49.7 \%$ and $5.6 \%$, respectively.

The municipality of Alto Parnaíba has the highest growth rate with 176.2\% between 2005 and 2015, followed by the municipality of Feira Nova do Maranhão with $165.5 \%$ and Tasso Fragoso with $70.8 \%$. In terms of average annual growth rate, Alto Parnaíba continues to present the highest value with $13.2 \%$, however, Tasso Fragoso soon after occupying the place of the municipality of Feira Nova do Maranhão with a rate of $12.8 \%$ and $11.1 \%$, respectively.

Complementing the micro-regional analysis, Chart 11 shows the GDP by sectors of the micro-region of Gerais de Balsas between the years 2005 to 2015. Looking at the graph, the importance of the service and agricultural sectors in the micro-region economy is evident, varying many their positions, this is because agriculture is an interdependent sector with services. The service sector had its highest increase in 2014 when it registered the amount of 1,011,955.26 billion reais, followed by 2013 with $860,271.47$ and 2015 with 797,949.21, the highest drop in the service sector in the The period analyzed was recorded in the year of 2007 with $489,032.63$ billion reals, soon after 2014 there was again a decrease in the year 2015 .

As pointed out previously, the agricultural sector is following the growth of the services sector and vice versa. The agricultural sector recorded its highest increase in 2014 with 938,837.18 billion reais, and then comes 2013 and 2015 with $900,582.07$ and $851,174.49$ billion reais respectively, the highest decrease was recorded in 2006 with 250,720.69 billion reais. Between 2007 and 
Citation: Gustavo de Oliveira Barbosa, et al., Analysis of the agro-industrial system in the region of Balsas - MA between the years from 2005 to 2017. Australian Journal of Basic and Applied Sciences, 13(5): 64-84. DOI: 10.22587/ajbas.2019.13.5.8

2008 there was an exponential growth of agricultural GDP in the microregion, registering a growth of $149.0 \%$ in this period, with constant growth of $56.5 \%$ between 2010 and 2014.

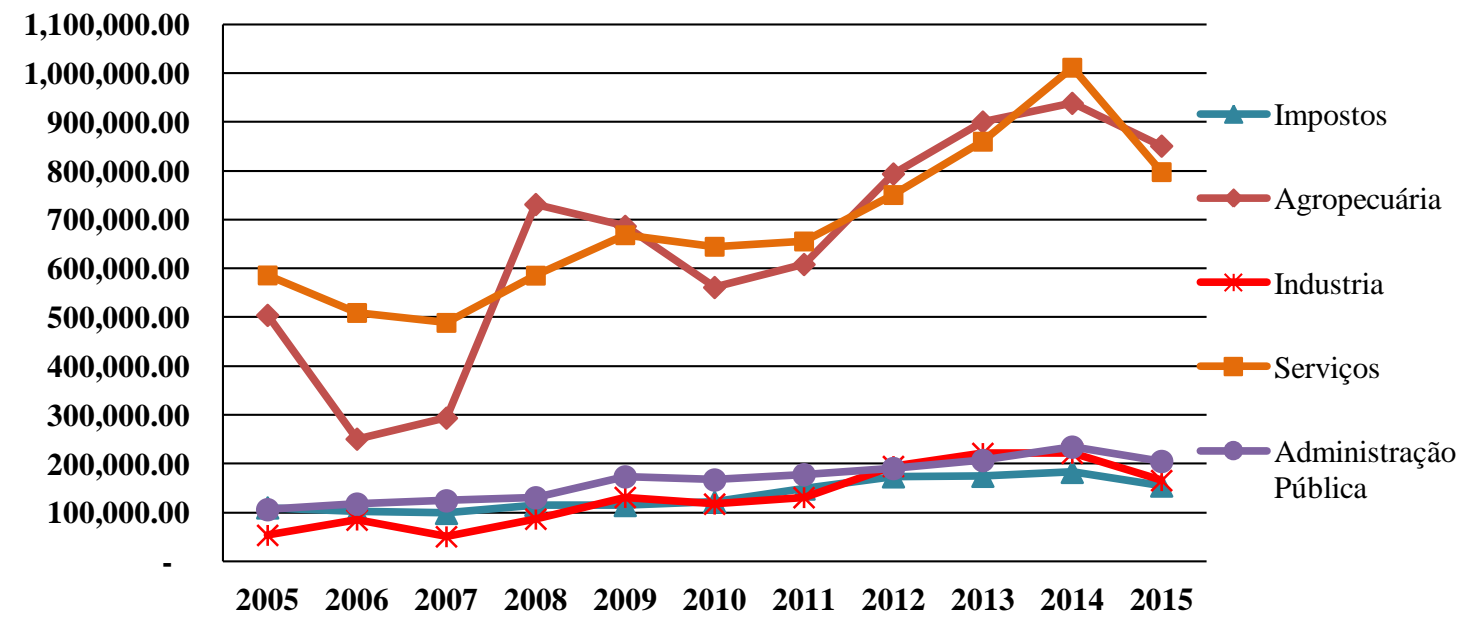

Graph 11. GDP per sector of the General Microregion of Ferries in Thousand Reais.

Source: Prepared by the author based on IBGE data (2017).

Note 1: IGP-Di deflated values.

The other sectors, in relation to the agricultural and livestock sectors and services, ended up presenting negligible numbers, concentrating $24.7 \%$ in the year of the highest sectoral growth in 2014 , which, in contrast to the agriculture and livestock sectors and services, concentrated $75,3 \%$ in the same year.

Table 8. Growth rate and average annual growth rate of GDP by sectors of the Microregion of Gerais de Balsas at real prices between the years 2005 to 2015 .

\begin{tabular}{|l|l|l|}
\hline Sectors & Growth rate & Average Annual Growth Rate \\
\hline Impostos & $40,8 \%$ & $4,1 \%$ \\
\hline Agropecuária & $68,7 \%$ & $13,9 \%$ \\
\hline Industria & $209,7 \%$ & $17,9 \%$ \\
\hline Serviços & $36,1 \%$ & $4,1 \%$ \\
\hline Administração Pública & $93,1 \%$ & $7,4 \%$ \\
\hline
\end{tabular}

Source: Prepared by the author based on IBGE data (2017).

Note 2: Deflated values by IGP-Di.

Table 8 shows the growth rate and the average annual GDP growth rate by sectors of the Gerais de Balsas microregion between the years 2005 and 2015, thus the information in Table 8 complements the information in Chart 11, which can deepen a little more than the previous analysis.

The sector of industry, despite being the smallest sector of the economy of the state of Maranhão was the sector that obtained the highest growth rate and the highest average annual growth rate in the micro region of Gerais de Balsas, presenting the rate of $209.7 \%$ and $17.9 \%$ respectively. Next comes the public administration with a growth rate of $93.1 \%$, agriculture and livestock ranks third with $68.7 \%$, taxes and services with $40.8 \%$ and $36.1 \%$.

After analyzing the average annual growth, secondly, after the industry sector with $17.9 \%$, the agricultural sector appears with $13.9 \%$, public administration in third place with $7.4 \%$, and, following the rate of growth, taxes with $4.1 \%$ and services also with $4.1 \%$ average annual growth rate. 


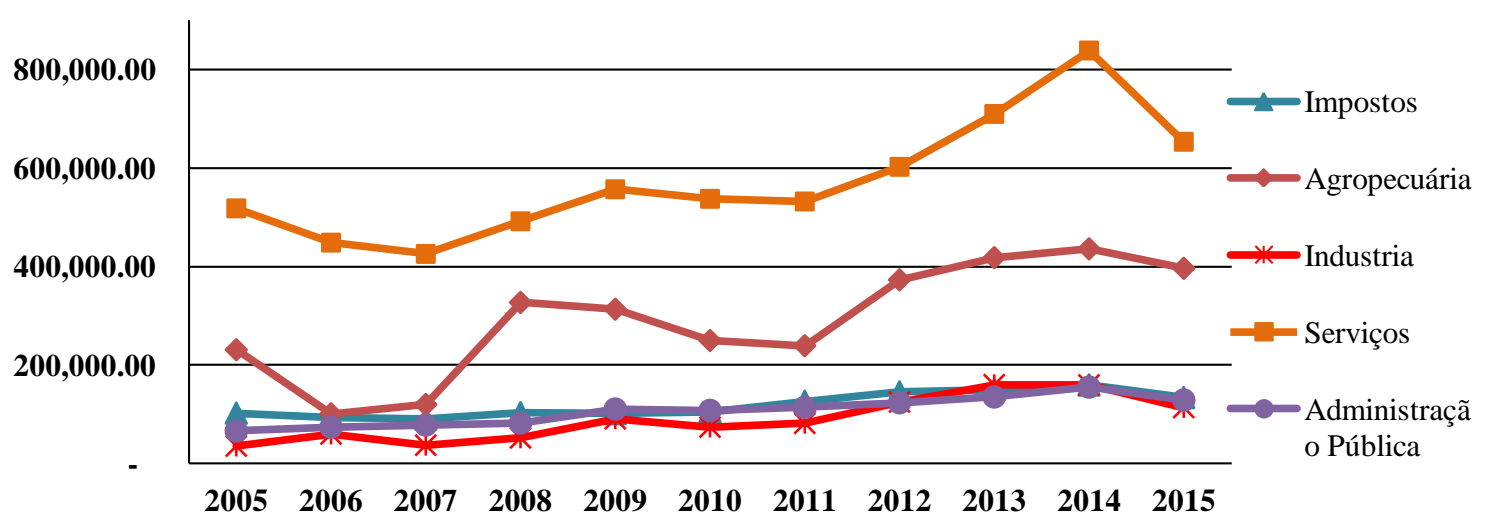

Graph 12. GDP by sectors of the municipality of Balsas in Thousand Reais

Source: Prepared by the author based on IBGE data (2017).

Note 1: IGP-Di deflated values.

Graph 12 shows the GDP of the municipality of Balsas by sector, the service sector with the highest increase in the period analyzed in 2014 when it registered the amount of 839,125.46 million reais followed by the year 2013 with 710.215,04, and to end the year 2015 with 653,621.96 million reais from a drop in the previous year. Then, in the year of 2014, the agricultural sector registered the highest increase in the analyzed period, with 436,063.41 million reais, then the year of 2013 with $418,079.99$ and the year of 2015 with 396,391.12 coming from a drop from the previous year.

Among the other three remaining sectors, taxes appear with the highest value, registering the highest increase also in 2014 with $159,366.72$ million reais followed by industry with $159,786.22$ in 2013 and public administration with $155,119.71$ million reais in year 2014.

Table 9. Growth rate and average annual growth rate of GDP by sectors of the municipality of Balsas at real prices between the years 2005 to 2015 .

\begin{tabular}{|l|l|l|}
\hline Sectors & Growth rate & Average Annual Growth Rate \\
\hline Impostos & $30,6 \%$ & $3,3 \%$ \\
\hline Agropecuária & $71,6 \%$ & $17,0 \%$ \\
\hline Indústria & $221,8 \%$ & $19,1 \%$ \\
\hline Serviços & $26,1 \%$ & $3,3 \%$ \\
\hline Administração Pública & $95,4 \%$ & $7,6 \%$ \\
\hline
\end{tabular}

Source: Prepared by the author based on IBGE data (2017).

Note 1: IGP-Di deflated values.

Table 9 shows the growth rate the growth rate and average annual GDP growth rate by sectors of the municipality of Balsas between the years 2005 to 2015 . Although service sector together with agriculture and livestock sector represent almost $73 \%$ of GDP the industry had the highest growth rate among the analyzed years, presenting $221.8 \%$ growth, followed by the public administration sector with $95.4 \%$, agriculture and cattle raising with $71.6 \%$, taxes grew by $30.6 \%$ Finally, services, the sector with the highest GDP in the previous graph, Graph 12, also obtained the lowest growth rate with $26.1 \%$. In terms of the average annual growth rate, the industrial sector continues with the highest rate with $19.1 \%$, the agricultural sector immediately follows with $17.0 \%$, public administration with $7.6 \%$, and finally with both $3.3 \%$ each, respectively, of services and taxes.

\section{METHODOLOGY}

We will use literature review on the proposed theme as well as subtopics that include the discussion of the subject worked through consultations in scientific articles, periodicals, books and theses in order to understand the growth dynamics and economic and social development of the favored region agricultural activity.

Secondary data survey relating the amount of effort to the production capacity collected on the RAIS sites, collection of quantities produced, as well as areas planted through the Agricultural Census collected on the IBGE website.

The most relevant approaches presented by the authors in the literature review stage will be organized and worked in conjunction with the data collected in the specialized sources in order to provide more theoretical basis to the topic that is always exposed, will be organized in tables, graphs and images for analysis posterior.

Finally, the information collected in the previous steps will be analyzed using the qualitative and quantitative methods, in order to observe the participations, growth relationships and / or dependencies with the variables analyzed. 


\subsection{Economic indicators}

\section{RESULTS AND DISCUSSION}

"Both locational theory and regional growth theory describe a typical sequence of the stages that regions go through in the course of their development" (NORTH, 1977, p.293). Such sequences are organized in stages of growth and economic development, the first stage of the regions is a subsistence economy phase, refers to an economy based on agriculture and the population is located according to the distribution of natural resources. The second stage is intrinsically related to improvements in transportation, the region then develops some trade and local expertise. (NORTH, 1977, p.293). The third stage is related to trade, with the increase in interregional trade the region tends to move through a succession of agricultural crops. The fourth stage is reached because of population growth and diminishing returns from agriculture and other extractive industries, the region is forced to industrialize (NORTH, 1977, p.294) and complements:

The early stages of industrialization are typically based on agricultural and forestry products and include activities such as food processing, wood artifacts, and textile fiber preparation. If industrialization continues, mineral and energy resources are of decisive importance. As a second stage of industrialization, we find industries (such as smelting, refining and metal processing, petroleum refining, chemical industries based mainly on coal, petroleum, potash, salt and other minerals, glass industry and ceramics. When there is cheap electricity, it becomes possible to deploy industries that need it in quantities (refining non-ferrous metals, metal alloys, special steels, artificial abrasives, etc.) as happened in Norway, Switzerland, the Tennessee Valley and in the Columbia River Valley (NORTH, 1977, p.294).

Finally, the fifth and final stage of regional development is when the region specializes in tertiary activities, producing for export. Therefore, at this stage, the region exports products, capital, labor and special services to less developed regions (NORTH, 1977, p.294).

Underlining such theories, North (1977, p.298) points out that this generalization of stages of regional development does not actually transpose what has occurred in European economic history. And it adds, "the development of an export article reflected a comparative advantage in the relative costs of production, including transfer costs. Distribution transfer costs served to limit the size of the export market "(NORTH, 1977, p.299).

According to North (1977: 303) "nodules grow because of special locational advantages, which decrease the costs of transferring and processing export articles. "Thus, according to North (1977: 303)," it is evident that this growth is closely linked to the success of its exports."

\subsubsection{Location Quotient (QL)}

For the deepening of the quantitative analysis, as stated by Alves (2012, p.40), the Locational Quotient (QL) is not only the most widespread and most used in the analysis, but also an indicator recommended by Isard (1972) and North (1977). According to North $(1977$, p.300) the location quotient compares the concentration of employment of a given industry in an area with another area. Thus, "this quotient shows the locational behavior of the branches of activity, as well as the more specialized (potential) sectors in the different regions" (Alves, 2012, p.40). The QL formula consists of:

$\mathbf{Q L}_{\mathrm{ij}}=\frac{\mathbf{E}_{\mathrm{ij}} / \sum_{\mathbf{i}} \mathbf{E}_{\mathrm{ij}}}{\sum_{\mathbf{j}} \mathbf{E}_{\mathrm{ij}} / \sum_{\mathbf{i}} \sum_{\mathbf{j}} \mathbf{E}_{\mathrm{ij}}}$

Onde:

$\mathrm{E}_{\mathrm{ij}}=$ Occupied People, in sector $\mathrm{i}$ of region $\mathrm{j}$;

$\sum_{\mathrm{j}} \mathrm{E}_{\mathrm{ij}}=$ Total number of persons employed in region $\mathrm{j}$;

$\sum_{\mathrm{i}} \mathrm{E}_{\mathrm{ij}}=$ Persons Occupied, of sector $\mathrm{i}$ in the reference region;

$\sum_{\mathrm{i}} \sum_{\mathrm{j}} \mathrm{E}_{\mathrm{ij}}=$ Total of persons employed in the reference region.

In this way, the QL compares the percentage participation of the employed persons of a region $\mathrm{j}$ with the percentage participation of the reference region. QL informs how often sector $i$ is more (or less) specialized, for the region $j$ vis-à-vis the macro-region of reference. Traditionally, specialization of the region $\mathrm{j}$ in the macro-regional context, in relation to the sector studied, is demonstrated when the QL assumes values above 1. In these cases, the sector will be specialized. The contract will occur when the QL is less than 1 (Alves, 2012, p.40).

Table 10 shows the comparison between the years 2006 and 2017 of the QL index by microregion of the state of Maranhão. For the mining sector, the highest index is presented by the Rosario micro-region, with 14,526 in 2006 and 21,652 in 2017, a variation of $49.1 \%$ from one year to the next, the Geral de Balsas micro-region presents a of 5,017 in 2006 and 1,214 in 2017, representing a fall of $75.8 \%$ in the variation, the microregion that presented the highest growth rate was the micro-region of Chapadas de Alto Itapecuru with $838.9 \%$. For the Transformation Industries sector, the Coelho Neto micro-region has the highest indexes with 3,388 in 2006 and in the year 2017 4,751, Gerais de Balsas had 0.472 in 2006 and 0.620 in 2017, a growth of 31, 3\%, the microregion with the highest growth rate is Baixo Parnaíba Maranhense with $640.7 \%$.

In the industrial services sector, the highest index is represented by the Caxias microregion, with the indexes of 2,192 in 2006 and 1,666 in 2017, Geral de Balsas's micro-region presents, in 2006, 0.432 and 0.455 in the year 2014, meanwhile. , the micro-region with the highest growth rate was the Lençóis Maranhenses microregion with $161.4 \%$. 
Citation: Gustavo de Oliveira Barbosa, et al., Analysis of the agro-industrial system in the region of Balsas - MA between the years from 2005 to 2017. Australian Journal of Basic and Applied Sciences, 13(5): 64-84. DOI: 10.22587/ajbas.2019.13.5.8

Table 10. Locational quotient by sectors of the Microregions of the state of Maranhão for the years 2006 and 2017.

Source: Prepared by the author from RAIS data (2017).

Note 1: Legend: QL $\geq 1$ = Specialized sector; $0.50 \leq \mathrm{QL} \geq 0.999=$ Medium-specialized sector; $\mathrm{QL} \leq 0.499=$ Non-specialized sector.

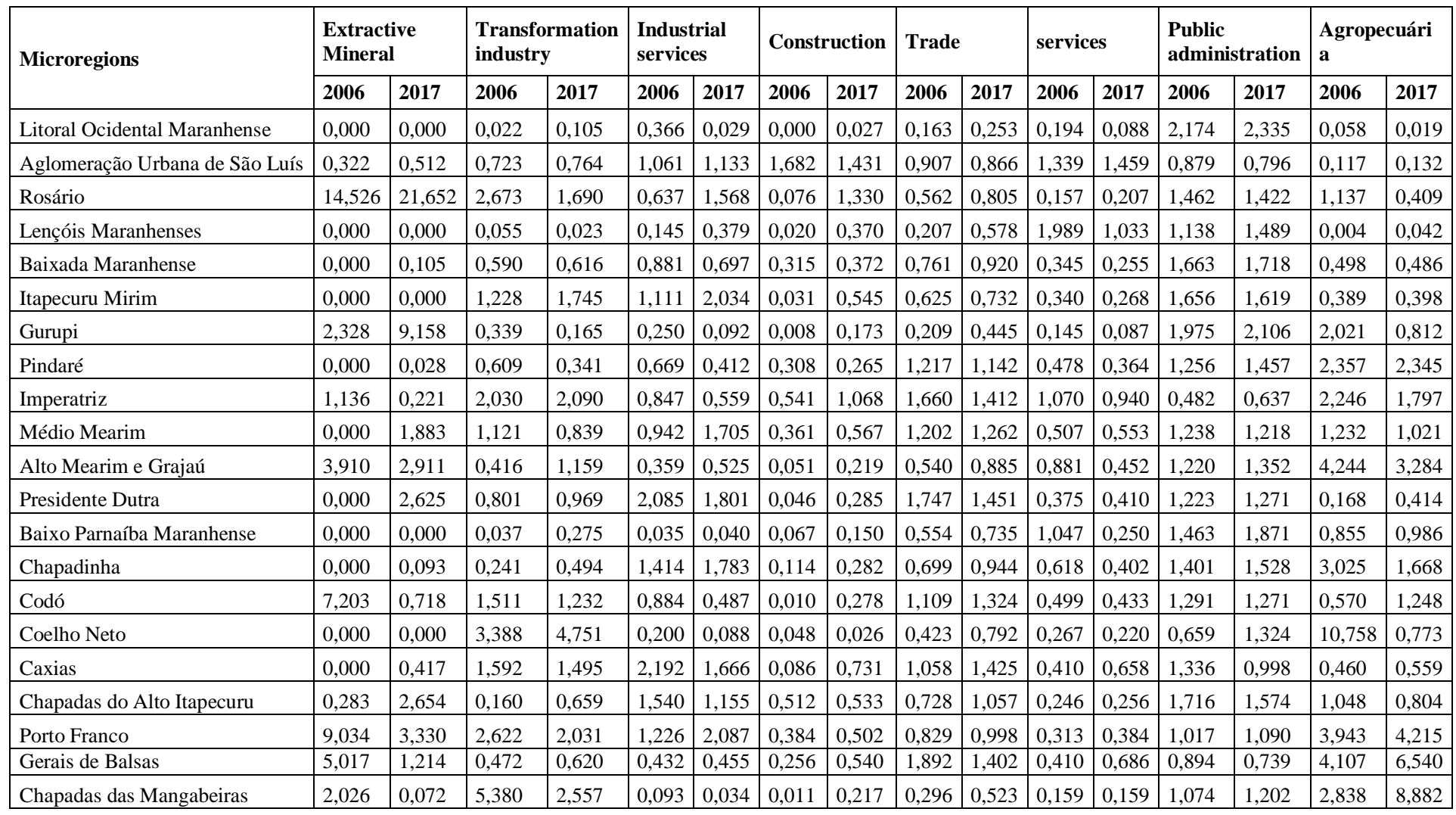

For the construction industry, the micro-region with the highest index is the micro-region of São Luís Agglomeration with 1,682 in 2006 and 1,431 in 2017, a fall of 14.9\% between the two years. Although it did not present a significant index, with only 0.010 in 2006 and in the year of 2017.278 , the Codó microregion was the one with the highest increase in the state, presenting a variation of $2,714.2 \%$ in the sector, the microregion of Gerais of Balsas also does not present a significant sector presenting the values of 0.256 in the year of 2006 and 0.540 in the year of 2017, however it had an expressive increase of $110.8 \%$ in the sector. For the commerce sector, the micro-region with the highest index is Gerais de Balsas, with values of 1,892 in 2006 and 1,402 in 2017 , despite the highest level, there was a drop of $25.9 \%$ from one year to the year another, the highest increase was in the Lençóis Maranhenses microregion with $179.9 \%$. In the services sector, the Lençóis Maranhenses microregion has the highest index with 1,989 in 2006 and 1,033 in 2017, followed by the São Luis urban agglomeration with 1,339 in 2006 and 1,459 in 2017, are the only microregions it presents significant indexes in the two years compared, the highest growth rate is represented by the Geral de Balsas micro-region with a rate of $67.5 \%$ and the lowest rate is presented in the micro-region of Baixo Paranaíba Maranhense. With the exception of the microregions of the Urban Agglomeration of São Luís, Imperatriz and of Gerais de Balsas, the Public Administration sector is in general the sector that presents the significant index in all microregions of the state, the greatest growth occurred in the micro region of Coelho Net of 101.0\% in 2006 and 2017, Gerais de Balsas had 0.894 in 2006 and in the year 2017 the index of 0.739 , a decrease of $.17 .4 \%$.

Finally, the agricultural sector has a significant index in the microregions of Pindaré, Imperatriz, Mearim, Alto Mearim and Grajaú, Chapadinha, Porto Franco, Gerais de Balsas and Chapadas das Mangabeiras, among them the one with the highest index and the highest rate of growth is the microregion of Chapada das Mangabeiras with 2,838 for the year 2006 and 8,882 for the year 2017, with 213.0\% growth rate, Gerais de Balsas presents 4,107, 6,540 for the year 2006 and 2017, respectively.

Figure 2 shows the numbers presented in Table 10 in a spatial manner in order to improve the observation in the dynamics of the microregion analyzed. In view of this, in relation to the mineral extractive sector of the microregion, the municipality of Balsas raised its index to "significant location". The municipalities of Riachão and Alto Parnaíba started to have "average location". This dynamics is probably due to the relative proximity to the Municipality of Ferries, which has the highest levels of attraction in relation to other municipalities, due to the greater market level and greater availability of labor. 
Citation: Gustavo de Oliveira Barbosa, et al., Analysis of the agro-industrial system in the region of Balsas - MA between the years from 2005 to 2017. Australian Journal of Basic and Applied Sciences, 13(5): 64-84. DOI: 10.22587/ajbas.2019.13.5.8

In the processing industry, the municipality of Riachão presented a change from "weak location" to "significant location", the municipality of Tasso Fragoso went from "weak location" to "average location", and finally, with "significant location", according to Figure 2.

The industrial, civil construction and commerce sectors remained "significant" in the municipality of Balsas, while the other municipalities in the micro-region had a "weak location" in the two periods analyzed. The service sector is also concentrated in the municipality of Balsas showing "significant location", the municipality of Alto Parnaíba changed from "significant location" to "average location".

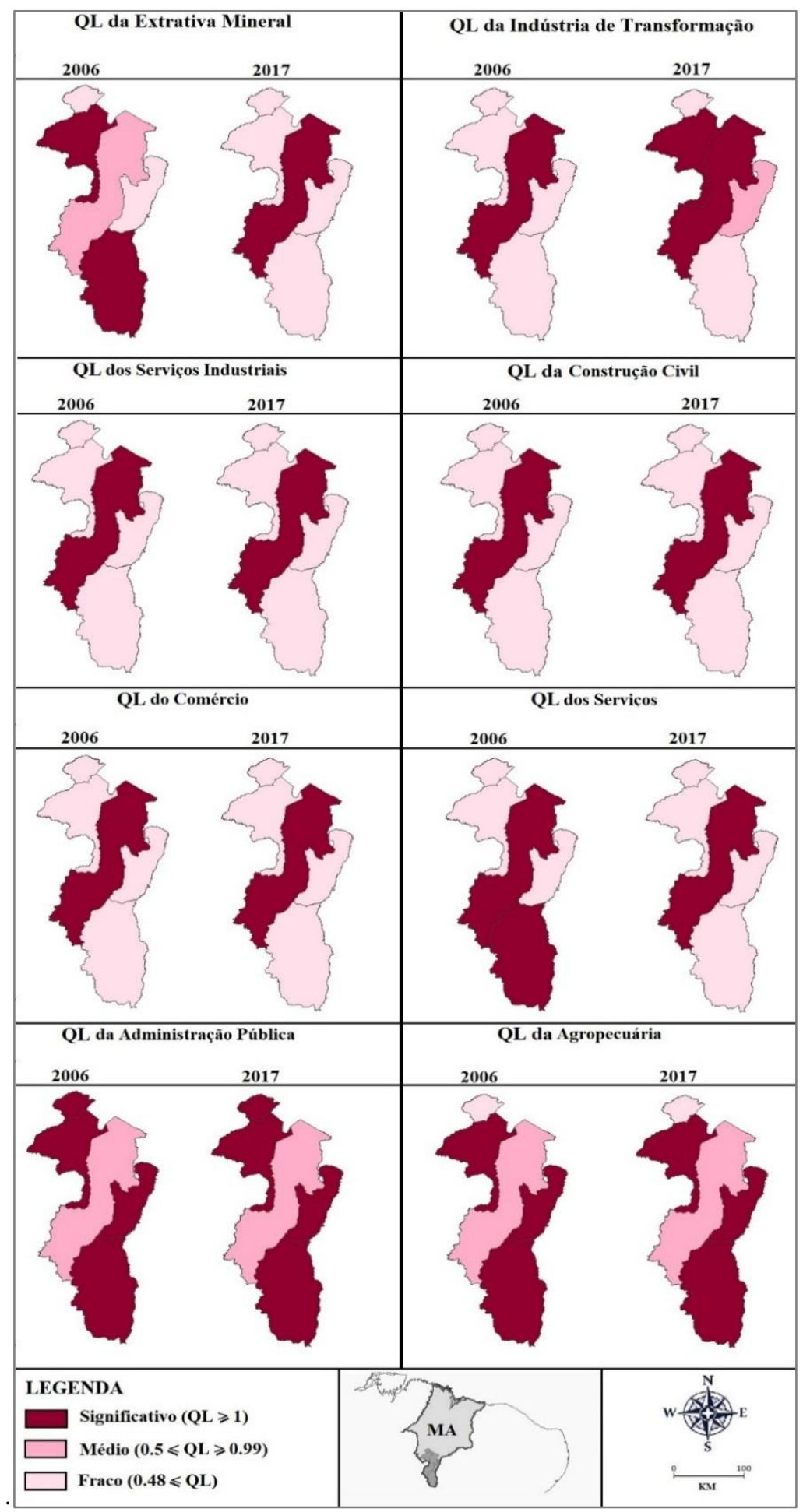

Figure 2. Locational quotient by sectors of the municipalities of the Microregion of Gerais de Balsas for the years 2006 and 2017 Source: Prepared by the author from RAIS data (2017).

Note 1: Legend: QL $\geq 1$ = Specialized sector; $0.50 \leq \mathrm{QL} \geq 0.999=$ Medium-specialized sector; QL $\leq 0.499=$ Non-specialized sector. 
Citation: Gustavo de Oliveira Barbosa, et al., Analysis of the agro-industrial system in the region of Balsas - MA between the years from 2005 to 2017. Australian Journal of Basic and Applied Sciences, 13(5): 64-84. DOI: 10.22587/ajbas.2019.13.5.8

The public administration together with agriculture and livestock are the great employers of the micro-region, however, in contrast to the entire micro-region, the municipality of Balsas presents "average location" for both sectors, expressively in the public administration, since in the agricultural sector the municipality of Feira Nova do Maranhão presents a "weak location" for the two years analyzed.

Table 11. Locational quotient by sectors of the municipalities of the Microregion of Gerais de Balsas for the years 2006 and 2017.

\begin{tabular}{|c|c|c|c|c|c|c|c|c|c|c|c|c|c|c|c|c|}
\hline \multirow[t]{2}{*}{ Counties } & \multicolumn{2}{|c|}{$\begin{array}{l}\text { Extractive } \\
\text { Mineral }\end{array}$} & \multicolumn{2}{|c|}{$\begin{array}{l}\text { Transformatio } \\
\mathbf{n} \text { industry }\end{array}$} & \multicolumn{2}{|c|}{$\begin{array}{l}\text { Industrial } \\
\text { services }\end{array}$} & \multicolumn{2}{|c|}{$\begin{array}{l}\text { Constructio } \\
\text { n }\end{array}$} & \multicolumn{2}{|c|}{ Trade } & \multicolumn{2}{|c|}{ services } & \multicolumn{2}{|c|}{$\begin{array}{l}\text { Public } \\
\text { administratio } \\
\text { n }\end{array}$} & \multicolumn{2}{|c|}{$\begin{array}{l}\text { Agropecuári } \\
\text { a }\end{array}$} \\
\hline & 2006 & 017 & 2006 & 017 & 2006 & 2017 & 2006 & 2017 & 2006 & 2017 & 2006 & 2017 & 2006 & 2017 & 2006 & 2017 \\
\hline $\begin{array}{l}\text { Alto } \\
\text { Parnaíba }\end{array}$ & 2,379 & $\begin{array}{l}0,00 \\
0\end{array}$ & 0,000 & 0,000 & $\begin{array}{l}0,35 \\
3\end{array}$ & $\begin{array}{l}0,00 \\
0\end{array}$ & $\begin{array}{l}0,00 \\
0\end{array}$ & $\begin{array}{l}0,00 \\
0\end{array}$ & $\begin{array}{l}0,15 \\
6\end{array}$ & $\begin{array}{l}0,36 \\
9\end{array}$ & $\begin{array}{l}1,07 \\
7\end{array}$ & $\begin{array}{l}0,26 \\
4\end{array}$ & 1,749 & 2,132 & 1,225 & 1,287 \\
\hline Balsas & 0,712 & $\begin{array}{l}1,23 \\
4\end{array}$ & 1,218 & 1,079 & $\begin{array}{l}1,22 \\
3\end{array}$ & $\begin{array}{l}1,22 \\
8\end{array}$ & $\begin{array}{l}1,26 \\
6\end{array}$ & $\begin{array}{l}1,25 \\
2\end{array}$ & $\begin{array}{l}1,23 \\
4\end{array}$ & $\begin{array}{l}1,17 \\
4\end{array}$ & $\begin{array}{l}1,15 \\
2\end{array}$ & $\begin{array}{l}1,19 \\
5\end{array}$ & 0,824 & 0,798 & 0,734 & 0,788 \\
\hline $\begin{array}{l}\text { Feira } \\
\text { Nova do } \\
\text { Maranhão }\end{array}$ & 0,000 & $\begin{array}{l}0,00 \\
0\end{array}$ & 0,000 & 0,000 & $\begin{array}{l}0,00 \\
0\end{array}$ & $\begin{array}{l}0,00 \\
0\end{array}$ & $\begin{array}{l}0,00 \\
0\end{array}$ & $\begin{array}{l}0,00 \\
0\end{array}$ & $\begin{array}{l}0,02 \\
2\end{array}$ & $\begin{array}{l}0,30 \\
0\end{array}$ & $\begin{array}{l}0,11 \\
4\end{array}$ & $\begin{array}{l}0,08 \\
0\end{array}$ & 2,592 & 3,082 & 0,028 & 0,027 \\
\hline Riachão & 4,267 & \begin{tabular}{|l|}
0,28 \\
2 \\
\end{tabular} & 0,494 & 1,366 & $\begin{array}{l}0,21 \\
9\end{array}$ & $\begin{array}{l}0,00 \\
0\end{array}$ & $\begin{array}{l}0,00 \\
0\end{array}$ & $\begin{array}{l}0,05 \\
1\end{array}$ & $\begin{array}{l}0,20 \\
0\end{array}$ & $\begin{array}{l}0,48 \\
6\end{array}$ & $\begin{array}{l}0,21 \\
5\end{array}$ & $\begin{array}{l}0,13 \\
6\end{array}$ & 1,852 & 1,916 & 1,248 & 1,332 \\
\hline $\begin{array}{l}\text { Tasso } \\
\text { Fragoso }\end{array}$ & 0,000 & $\begin{array}{l}0,00 \\
0\end{array}$ & 0,000 & 0,757 & $\begin{array}{l}0,00 \\
0\end{array}$ & $\begin{array}{l}0,30 \\
7\end{array}$ & $\begin{array}{l}0,00 \\
0\end{array}$ & $\begin{array}{l}0,00 \\
0\end{array}$ & $\begin{array}{l}0,03 \\
6\end{array}$ & $\begin{array}{l}0,14 \\
5\end{array}$ & $\begin{array}{l}0,31 \\
1\end{array}$ & $\begin{array}{l}0,35 \\
8 \\
\end{array}$ & 1,046 & 1,109 & 4,182 & 3,097 \\
\hline
\end{tabular}

Source: Prepared by the author from RAIS data (2017).

Note 1: Legend: QL $\geq 1=$ Specialized sector; $0.50 \leq \mathrm{QL} \geq 0.999=$ Medium-specialized sector; $\mathrm{QL} \leq 0.499=$ Non-specialized sector.

In order to quantitatively raise the QL values for the micro-region analyzed, complementing Figure 2, Table 11 shows the numbers for the years 2006 and 2017. In view of this, with the exception of the public administration and agriculture sectors, the municipality of Balsas shows a significant index in all sectors, in contrast to the other municipalities that have a significant index in the sector of public administration and Agriculture, with the exception of the municipality of Feira nova do Maranhão, which has a significant index only in Public Administration.

Although the municipality of Balsas had the highest number of specialized sectors, half of the sectors fell in the index for the year 2006 to 2017, being the sectors of transformation industry, construction, commerce and public administration, among them, the sector which is more specialized is the civil construction sector presenting the indexes of 1,266 and 1,252 for the year 2006 and 2017 , respectively, the sector that suffered the biggest drop was the manufacturing industry sector, with the negative rate of 11 , $4 \%$. The mining and quarrying industry is the sector with the highest growth rate in the analyzed years, representing a growth of $73.3 \%$.

\subsubsection{Hirshiman-Herfindahl Index (IHH)}

The Hirshiman-Herfindahl concentration index (HHI) is used to measure a sector's attractiveness in relation to other activities, the indicator consists of "division of the participation of sector $i$ of region $j$ into the total of sector $i$ of the region of reference, with the participation of the total of region $\mathrm{j}$ over the total of the reference region ". (Alves, 2012, p.42).

Alves (2012, p. 42) complements, when the HHI presents a positive value, indicates that sector $\mathrm{i}$ of region $\mathrm{j}$ is more concentrated, in this way sector $\mathrm{i}$ will have a greater attraction power in relation to the other sectors, given its level of specialization. The opposite will be done for the negative values, which will indicate a low attraction power in relation to the reference region, the IHH formula consists of:

$\mathbf{I H H}=\frac{\mathbf{E}_{\mathrm{ij}}}{\sum_{\mathbf{i}} \mathbf{E}_{\mathrm{ij}}}-\frac{\sum_{\mathbf{j}} \mathbf{E}_{\mathrm{ij}}}{\sum_{\mathrm{i}} \sum_{\mathbf{j}} \mathbf{E}_{\mathrm{ij}}}$

Onde:

$\mathrm{E}_{\mathrm{ij}}=$ Occupied People, in sector $\mathrm{i}$ of region $\mathrm{j}$;

$\sum_{\mathrm{j}} \mathrm{E}_{\mathrm{ij}}=$ Total number of persons employed in region $\mathrm{j}$;

$\sum_{\mathrm{i}} \mathrm{E}_{\mathrm{ij}}=$ Persons Occupied, of sector $\mathrm{i}$ in the reference region;

$\sum_{\mathrm{i}} \sum_{\mathrm{j}} \mathrm{E}_{\mathrm{ij}}=$ Total of persons employed in the reference region.

Table 12 shows the comparison between the years 2006 and 2017 of the IHH by municipality of the Gerais de Balsas microregion, such data complement the data in the previous table, which in the end end up becoming very similar. The municipality of Balsas has the highest indices in the mining, processing industry, industrial services, civil construction and services sectors, and in the sectors of public administration and agriculture there are no significant indices, unlike other municipalities in the microregion that present higher indices in the sectors of public and agricultural administration, and in the other sectors do not present significant indexes. 
In spite of presenting the largest HHI, for the significant sectors, except for the sectors of industrial services and services, all other sectors had a decrease in the HHH from the year 2006 to 2017, the services sector had a growth rate of 28, 9\% and industrial services a growth rate of $3.0 \%$. The sector that had the biggest drop in the rate was the mineral extraction sector in the municipality with a negative rate of $181.8 \%$. The highest growth is presented in the municipality of Tasso Fragoso where it registered an $\mathrm{IHH}$ of 0.003 in the year of 2006 and 0.008 in the year of 2017 in the sector of public administration, having a variation of $170.8 \%$.

Table 12. IHH by sectors of the municipalities of the Microregion of Gerais de Balsas for the years 2006 and 2017.

\begin{tabular}{|c|c|c|c|c|c|c|c|c|c|c|c|c|c|c|c|c|}
\hline \multirow[t]{2}{*}{ Counties } & \multicolumn{2}{|c|}{$\begin{array}{l}\text { Extractiv } \\
\text { e Mineral }\end{array}$} & \multicolumn{2}{|c|}{$\begin{array}{l}\text { Transformati } \\
\text { on industry }\end{array}$} & \multicolumn{2}{|c|}{$\begin{array}{l}\text { Industria } \\
\text { I services }\end{array}$} & \multicolumn{2}{|c|}{$\begin{array}{l}\text { Constructi } \\
\text { on }\end{array}$} & \multicolumn{2}{|c|}{ Trade } & \multicolumn{2}{|c|}{ services } & \multicolumn{2}{|c|}{$\begin{array}{l}\text { Public } \\
\text { administrati } \\
\text { on }\end{array}$} & \multicolumn{2}{|c|}{$\begin{array}{l}\text { Agropecuá } \\
\text { ria }\end{array}$} \\
\hline & $\begin{array}{l}200 \\
6\end{array}$ & \begin{tabular}{|l|}
201 \\
7
\end{tabular} & 2006 & 2017 & $\begin{array}{l}200 \\
6\end{array}$ & $\begin{array}{l}201 \\
7\end{array}$ & 2006 & 2017 & $\begin{array}{l}200 \\
6\end{array}$ & $\begin{array}{l}201 \\
7\end{array}$ & $\begin{array}{l}200 \\
6\end{array}$ & $\begin{array}{l}201 \\
7\end{array}$ & 2006 & 2017 & 2006 & 2017 \\
\hline Alto Parnaíba & 0,07 & $\begin{array}{l}- \\
0,05\end{array}$ & $-0,05$ & $-0,05$ & $\begin{array}{l}- \\
0,03\end{array}$ & $\begin{array}{l}- \\
0,05 \\
\end{array}$ & $\begin{array}{l}- \\
0,05\end{array}$ & $\begin{array}{l}- \\
0,05\end{array}$ & $\begin{array}{l}- \\
0,04\end{array}$ & $\begin{array}{l}- \\
0,03 \\
\end{array}$ & 0,00 & $\begin{array}{l}- \\
0,04 \\
\end{array}$ & 0,04 & 0,06 & 0,01 & 0,01 \\
\hline Balsas & $\begin{array}{l}- \\
0,23\end{array}$ & 0,19 & 0,17 & 0,06 & 0,18 & 0,18 & 0,21 & 0,20 & 0,18 & 0,14 & 0,12 & 0,15 & $-0,14$ & $-0,16$ & $-0,21$ & $-0,17$ \\
\hline $\begin{array}{l}\text { Feira Nova do } \\
\text { Maranhão }\end{array}$ & 0,02 & $\overline{-}-02$ & $-0,02$ & $-0,02$ & $-\overline{0}, 02$ & $\begin{array}{l}- \\
0,02 \\
\end{array}$ & $\begin{array}{l}- \\
0,02\end{array}$ & $\begin{array}{l}- \\
0,02 \\
\end{array}$ & $\begin{array}{l}- \\
0,02\end{array}$ & $\begin{array}{l}- \\
0,01 \\
\end{array}$ & $-\overline{0}, 02$ & $\begin{array}{l}- \\
0,02 \\
\end{array}$ & 0,04 & 0,04 & $-0,02$ & $-0,02$ \\
\hline Riachão & 0,25 & $\begin{array}{l}- \\
0,05\end{array}$ & $-0,04$ & 0,02 & $\begin{array}{l}- \\
0,06\end{array}$ & $\begin{array}{l}- \\
0,06\end{array}$ & $\begin{array}{l}- \\
0,08\end{array}$ & $\begin{array}{l}- \\
0,06\end{array}$ & $\begin{array}{l}- \\
0,06\end{array}$ & $\begin{array}{l}- \\
0,03\end{array}$ & $\begin{array}{l}- \\
0,06\end{array}$ & $\begin{array}{l}- \\
0,05\end{array}$ & 0,06 & 0,06 & 0,02 & 0,02 \\
\hline Tasso Fragoso & $\begin{array}{l}- \\
0,06\end{array}$ & $\begin{array}{l}- \\
0,07\end{array}$ & $-0,06$ & $-0,02$ & $\begin{array}{l}- \\
0,06\end{array}$ & $-\overline{0}$ & $\begin{array}{l}- \\
0,06\end{array}$ & $\begin{array}{l}- \\
0,07\end{array}$ & $\begin{array}{l}- \\
0,06\end{array}$ & $\begin{array}{l}- \\
0,06\end{array}$ & $\begin{array}{l}- \\
0,04\end{array}$ & $\begin{array}{l}- \\
0,05\end{array}$ & 0,00 & 0,01 & 0,20 & 0,15 \\
\hline
\end{tabular}

Source: Prepared by the author from RAIS data (2017).

Note 1: Legend: $\mathrm{IHH}>0=$ Concentrated sector; $\mathrm{IHH}<0=$ Unconcentrated sector.

Analyzing the Hirschman-Herfindahl concentration index (HHI) in a spatial way, it can be seen that the public administration and the agriculture and cattle raising have attraction in most of the municipalities of the microregion, except for the municipality of Balsas, which, in contrast, has a greater attraction in the sectors of manufacturing industry, industrial services, construction, commerce and services in the two years analyzed and in the extractive mineral sector only attracts in the years of 2017.

The analysis of QL is reaffirmed in the analysis of the IHH, in addition, for the mineral extraction sector, the districts of Riachão and Alto Parnaíba were no longer attractive in comparison from one year to the other, and the municipality of Balsas to exercise attraction in the last period. In civil construction, the municipality of Balsas became the only attraction in 2006, passing in 2017, to share such attraction with the municipality of Riachão.

There was a change in the service sector only in the municipality of Alto Parnaíba, thus leaving no attraction in the sector, possibly concentrating services in the municipality of Balsas.

\section{FINAL CONSIDERATIONS}

In an attempt to analyze the peculiarities, as well as the economic potential of the state of Maranhão before the national economy, analyzing the dynamics of the sectors and the growth presented in secondary data. In order to narrow the problem, the microregional point of view, in this case, the micro-region of Gerais de Balsas, located in the great southern region of the state, is analyzed.

In order to understand the historical dynamics of agricultural growth in the state, in the graphs and tables presented, relating in general the number of agricultural establishments and the area of these establishments, the inverse force of the growth of both variables is evident, in other words, when one of the variables grows, the other one decreases, and the total area does not grow in due proportions, emphasizing, therefore, a tendency of concentration in large areas not only in the micro region of Gerais de Balsas, but as for the whole state, since such concentration occurred in other microregions more abruptly than in the analyzed microregion.

With the agroindustrial growth, the level of technification in the field starts to increase in an analogous way, experiencing, thus, a great increase in the level of productivity of the field. It was proposed, for a comparison, to relate the planted area to the area, in hectares, between 2017 and 2018 for all the states of Maranhão, based on IBGE data, and although the data for the year 2018 was incomplete, ending in September, it was evident the increase in productivity in agriculture from one year to the next, increasing the hypothesis of an increase in the level of technification of Maranhão agriculture as well as the increase of agroindustrial units. GDP appears in order to become a rankin6g among the microregions of the state, the Geral de Balsas microregion is the fifth with the highest GDP of the state in both the years of 2005 and 2015, being below the Agglomeration microregions Urbanization of São Luís, Imperatriz, Pindaré, Caxias. With the intuition of deepening the analysis, the graph of GDP of the sectors is excellent to try to understand such dynamics, being clear in the graph the superiority of the services sector in the Maranhão economy, agriculture is the smallest sector in the state. However, in order to relate and understand the agricultural sector, Chart 9 brought 
only this sector, ranking by micro-region, to indicate which would have produced more in the year 2015, and in a surprising way, the micro-region of Gerai de Balsas appears well in the compared to other microregions, thus indicating a level of specialization as well as a comparative advantage compared to other microregions.

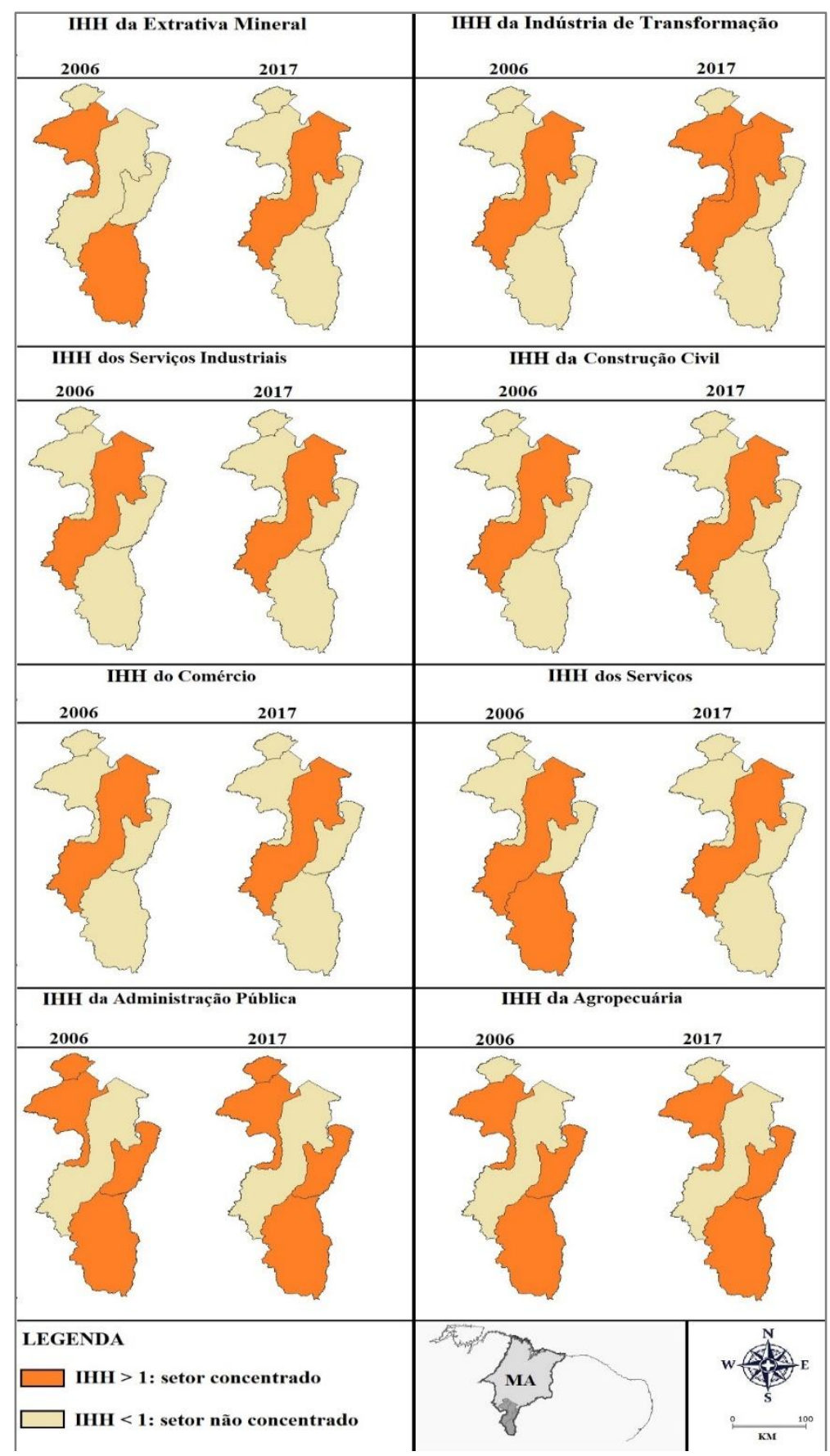

Figure 3. IHH by sectors of the municipalities of the Microregion of Gerais de Balsas for the years 2006 and 2017

Source: Prepared by the author from RAIS data (2017).

Note 1: Legend: $\mathrm{IHH}>0=$ Concentrated sector; $\mathrm{IHH}<0=$ Unconcentrated sector.

Until then, the municipality of Balsas is the municipality with the largest GDP in the micro region of Gerais de Balsas, and, relating the graph remaining in the analysis, it is evident the positive relation with which the municipality presents itself economically in the state. As pointed out earlier, the service sector is triggering the sector with the highest production in the state, in a similar way, the services sector in the micro region of Gerais de Balsas also appears as the largest GDP followed by the agricultural sector, being also perceived there analyzing the GDP by micro region of the municipality of Balsas, whose service sector holds the highest GDP followed by the agricultural sector. 
Confronting this information, we used the data provided by the RAIS to elaborate the Locational Quotient (QL) and the Hirshiman-Herfindahl Index (HHI) in order to quantitatively visualize the potential of the microregion. The surprise in this case arose when faced with the QL of the agricultural sector of the microregion, once the municipality of Balsas has the highest agricultural GDP would be evident that it would present the highest quotient, entertaining, it was found otherwise, the municipalities of Riachão , Alto Parnaíba and Tasso Fragoso, municipalities bordering the municipality of Balsas had a higher locational quotient. Following the previous graphs, which showed the superiority of the service sector in the micro-region, such superiority is concentrated represented all over the municipality of Balsas, the industries of Transformation Industries, industrial services, construction and commerce are highly concentrated in the municipality presenting, carrying, it is evident that the municipalities around Balsas carry out the planting of agricultural products and, after harvesting, these products are concentrated in ferries for processing and / or commerce, obtaining, thus, more attraction in relation to the other municipalities, thus becoming evident an agro-industrial structure relatively developed for the current economic level.

Therefore, referring to the theory of the production chain that such dynamics is composed of several links that are articulated with each other, one can see in the analyzes the interdependence among several sectors of the municipality. Generally speaking, there are producers around the municipality, processors, wholesalers, distributors, service providers, retailers and consumers are now concentrated in the municipality of Balsas. In this way, it is clear the existence of an industrial complex very well generated in the microregion, with great agroindustrial growth potential in the municipality of Balsas.

\section{REFERENCES}

ALVES, L. R. (2012) Indicadores de localização, especialização e estruturação regional. In: PIACENTI, C. A.; FERRERA DE LIMA, J. (Orgs.). Análise regional: metodologias e indicadores. Curitiba: Camões.

DÖRNER, S. H. (2017) - Análise do sistema agroindustrial da soja e seus efeitos sobre o desenvolvimento econômico e social do Maranhão / Stefan Hubertus Dörner. - Toledo, PR: [s. n.].

INSTITUTO BRASILEIRO DE GEOGRAFIA E ESTATÍSTISCA (IGBE) - Produto Interno Bruto dos Municípios Disponível em: < https://sidra.ibge.gov.br/pesquisa/pib-munic/tabelas >. Acesso em: 10 nov. 2018.

INSTITUTO BRASILEIRO DE GEOGRAFIA E ESTATÍSTISCA (IGBE) - Censo Agropecuário 2017 - Resultados Preliminares - Disponível em: < https://sidra.ibge.gov.br/pesquisa/censo-agropecuario/censo-agropecuario-2017 >. Acesso em: 18 ago. 2018.

INSTITUTO BRASILEIRO DE GEOGRAFIA E ESTATÍSTISCA (IGBE) - Censo Agropecuário 2006. Médio Produtor Ministério da Agricultura, Pecuária e Abastecimento - Disponível em: < https://sidra.ibge.gov.br/pesquisa/censoagropecuario/censo-agropecuario-2006/dados-sobre-medio-produtor-mapa-em-2006 >. Acesso em: 10 nov. 2018.

INSTITUTO BRASILEIRO DE GEOGRAFIA E ESTATÍSTISCA (IGBE) - Levantamento Sistemático da Produção Agrícola - outubro 2018 - Disponível em: < https://sidra.ibge.gov.br/home/lspa/brasil >. Acesso em: 05 nov. 2018.

NORTH, D. (1977). Teoria da localização e crescimento econômico regional In: J. SCHWARTZMANN (Org) Economia regional e urbana: textos escolhidos. Belo Horizonte: UFMG, p.333-343.

RELAÇÃO ANUAL DE INFORMAÇÕES SOCIAIS (RAIS) - Bases Estatísticas RAIS e CAGED - Disponível em: < http://bi.mte.gov.br/bgcaged/login.php >. Acesso em: 03 nov. 2018.

SILVA, J. G. (1996). A Nova Dinâmica da Agricultura Brasileira. Campinas, Instituto de Economia/ Unicamp. 